\title{
GLAD YOU'RE HERE
}

\author{
by \\ Lisa Kannakko \\ BAA Photographic Arts, Ryerson University, 1996
}

A Major Research Paper
presented to Ryerson University

in partial fulfillment of the

requirements for the degree of

Master of Fine Arts

in the program of

Documentary Media

Toronto, Ontario, Canada, 2019

CLisa Kannakko, 2019 


\section{Author's Declaration}

I hereby declare that I am the sole author of this MRP. This is a true copy of the MRP, including any required final revisions.

I authorize Ryerson University to lend this MRP to other institutions or individuals for the purpose of scholarly research.

I further authorize Ryerson University to reproduce this MRP by photocopying or by other means, in total or in part, at the request of other institutions or individuals for the purpose of scholarly research.

I understand that my MRP may be made electronically available to the public. 


\begin{abstract}
Glad You're Here

Lisa Kannakko

Master of Fine Arts

Documentary Media

Ryerson University, 2019
\end{abstract}

This paper is written in support of the ten-minute film Glad You're Here, a visually stunning personal film, told through the eyes of an artist.

Engaging themes of love and betrayal, hope, belonging and place, Glad You're Here documents my nineteen--year journey through building a family life, seeing it suffer the damage of mental illness, grief and separation, and then rebuilding with empathy. A story about an extreme moment of crisis has turned into a documentary that deals not just with the subjective but with the important issue of spousal abuse.

The story is summarized, and context is provided. Ethical issues in autobiographical film are discussed with regard to motive, consent, and disclosure. Issues specific to filming family, treatment of archival material, and use of place and landscape are considered. The film's social relevance is contextually set in reference to autoethnography and an existing body of work concerning trauma. 


\section{Acknowledgements}

Special thanks to my generous advisory team, Pierre Tremblay and Marc Glassman.

Your thoughtful discussion, discerning analyses, and insightful suggestions were invaluable to me from the beginning. Thank you for your enthusiasm and patient support. Your continually candid feedback prepared me for and sustained me throughout production and your encouragement made it possible for me to move forward in the face of doubt. I am so grateful to you both.

Deep thanks to Stephan Morel. Your kind words in moments of dread pulled me out of endless rabbit holes, pushed me to take the work beyond my comfort zone and ultimately gave me the courage to make the best work possible.

Thank you to Kate Monro for reading every draft I've sent, listening to every story I've told. You are my wall to bounce ideas, you are irreplaceable, and I am lucky to have your friendship.

Eternal gratitude to Laurel Fynes, for knowing my every fear since I was 5 years old, and always telling me the truth when I've been blinded.

Greatest thanks to my incredible Mother. Your enthusiasm, humour and encouragement has given me the courage, determination and confidence to make my life better each day; to never let my life be determined by another, or to live with denial. Your unconditional love and care mean everything to me. 


\section{Dedication}

This work is dedicated to my daughter, Sophia.

We do not marry to please our partner but to meet in the middle; with love, joy, appreciation, laughter, courage, kindness, creativity, listening, gentleness and generosity. I love you always. 
TABLE OF CONTENTS

PROJECT DESCRIPTION AND RATIONALE MY MARRIAGE

THE STORY COMES, AFTER THE ACCIDENT

Page 1

DOCUMENTING DAILY LIFE

Page 6

Page 11

DOCUMENTARY RELEVANCE

DOMESTIC ETHNOGRAPHY

Page 13

DOCUMENTARY PRACTICE FOR CHANGE

Page 18

EMPOWERING SILENT VOICES

Page 21

REPRESENTING TRAUMATIC EXPERIENCE

Page 24

METHODOLOGY

FINDING MY VOICE

Page 28

ENTER: MY FILM

Page 31

TRUSTING THE EDITOR WITHIN

Page 36

ENTER: STEFAN MOREL, ADVISING EDITOR

Page 39

SELECTED RESPONSES

Page 43

SCRIPT

Page 44

CONCLUSION

Page 55

BIBLIOGRAPHY

Page 57 


\title{
PROJECT DESCRIPTION AND RATIONALE
}

\author{
MY MARRIAGE
}

What do you do when a major life change occurs, and nothing is understandable? For myself, I decided to make an autobiographical film. What I expected to disclose through this work became a fraction of the truth I shared. It evolved into a search for the root cause of my divorce.

Subconsciously I was affected by a trauma that I had blocked out. I was inevitably forced by repeated flashbacks of memories that were inescapable, starting a search through my archive to uncover the truth of my experience and take a step towards healing and taking ownership of my past.

In the process I put myself center stage, with my daughter, husband, failed family business, and home as secondary characters. It is a story told from my perspective, as I have no right to speak for others. This project was intended to be an art therapy piece.

I used footage from my archive of nineteen years, including home movies shot on a variety of small point and shoot digital cameras: iPhones, Canon DSLRs and still images. I poured through twenty-two external hard drives to collect moments that gave context to this story.

Before entering Ryerson University's Documentary Media MFA program, I had run a successful photography business, shared the operation of a cafe/bar with my husband, and was a stay at home mom to our only child, a daughter. I focused on being the best mother and wife I could be 
while pursuing my creative ideas in an attempt to build our future. When things started to fall apart, I chose to carry on, hoping I could fix our problems as I had fixed everything else. I was deeply naive of the effects my husband's undiagnosed mental illness would have on our lives. It was not clear until the end, and even now parts of it are baffling.

Leading up to this time I had felt entitled to have a certain kind of lifestyle due to my being at a certain age and time in my life, being a homeowner, growing up middle-class in Canada with certain privileges and freedoms; culminating in a strong desire for an archetypical marriage. As my seventeen-year marriage collapsed, my sense of entitlement blinded me. I was also isolated from the world due to the nature of my relationship. Regardless of what direction I turned, I was told that things were my fault, and it was easier for me to ignore, and therefore accept, the increasing violence in my home, than to stop it, and I switched to survival mode.

Once I had removed myself from the situation, I started to have flashbacks. I couldn't turn off my mind, or stop revisiting blocked out moments of violence. Everything intimate, even holding my cat, became a trigger. These memories of trauma were the strongest motivator for creating this work.

Making the film was a long, slow process. I was hesitant to share my feelings and experiences, but I felt I had no choice. At first, it was all raw anger, putting my classmates at a disadvantage when providing feedback. In time, the film created a distance for reflection and became a form of art therapy that was cathartic and brought me freedom. I was able to examine what had happened and take ownership of my story. 
By sharing the details of my story, I no longer felt alone. At the public screening and reception of my documentary, it was revealed that many other people experience this side of marriage. My story hit common markers and connected with other people's experience of trauma. The film also gave me a way to relate to my pain so that I could be free of it and begin to move forward and start over. I don't believe that I would feel this good if I hadn't made this film and I'd probably still be unable to make sense of the situation.

The process of searching through my archive for moments that fell together perfectly was emotionally and physically labour intensive. Watching past moments of joy through the prism of grief while not knowing what the future would hold opened the floodgates for depression, and at the same time offered a path forward. At first, many of my memories of the past were repressed and I used a visual language to describe my feelings. Eventually, I juxtaposed the visuals with audio stories of trauma. In one case, the beauty of time-lapse photography of a location in nature, looking up at the stars in the night, invites the viewer to contemplate our place in the universe. By sharing my grief with the audience, I was able to put some of the trauma from the present moment into the past, taking it out of my heart and putting it into the project.

Glad You're Here functions as a work of autoethnography. "Autobiography becomes ethnographic at the point when the film or video-maker understands his or her personal history to be implicated in larger social formations and historical processes." ${ }^{1}$ It allowed me the opportunity to reevaluate my old narrative and change my inner perception of this story from a

\footnotetext{
${ }^{1}$ Russell, Catherine. Autoethnography: Journeys of the Self, In Experimental Ethnography: The work of Film in the Age of Video, 274-314. Durham, Duke University Press. 1999. P. 276.
} 
place of victim to a place of release and renewal. From a place of silence and acceptance to a place of empowerment.

The need to tell my own story in a work of autobiographical performance created an opportunity for others to bear witness to events in my life and to explore the relationship between the personal and the political. Personal narrative performance is a genre that has become necessary as our mobile society separates us from close relationships with those in our community. The distinguished Dr. Linda M. Park-Fuller, an expert on performance, has written "We are hungry to know what other ordinary people think, how they cope, how they survive. We need to 'bear witness' to their confrontation of trials and losses, in order to cope with our own [problems]."

In sharing our stories, we also receive some relief from debilitating memories of the past, because otherwise, silence becomes a trap. A victim may begin to blame themselves, with negative psychological consequences.

"That the speakers about trauma on some level prefer silence so as to protect themselves from the fear of being listened to - and listening to themselves. That while silence is defeat, it serves them both as sanctuary and as a place of bondage."3 For as long as we are silent about our story there can be no escaping what has happened. The incident can hold us, affect us, perhaps even control us.

\footnotetext{
2 Park-Fuller, Linda M. Performing Absence: The Staged Personal Narrative as Testimony. Text and Performance Quarterly. Vol. 20, No. 1, January 2000, pp.21.

${ }^{3}$ Felman, S., \& Laub, D. (1992). Testimony: Crises of witnessing in literature, psychoanalysis, and history. Florence, KY, US:

Taylor \& Frances/Routledge. P. 58
} 
The Yale literary critic Shoshana Felman and psychoanalyst Dora Laub in Testimony: Crises of witnessing in literature, psychoanalysis, and history, wrote that "None find peace in silence, even when it is their choice to remain silent." ${ }^{4}$ What has happened to us changes us, they note: it has effects we might not even see, as we are so close to the surface. "Survivors who do not tell their story become victims of a distorted memory [...] The 'not telling' of the story serves as a perpetuation of its tyranny." ${ }^{\circ 5}$ Traumatic events can serve as a roadblock within our life that diverts us to a new less positive path, taking with it our hopes, our dreams, creating a sense of reality far from where we stood before the incident. We become a changed person with no way back to our true selves unless we take steps to address the injury. "The events become more and more distorted in their silent retention and pervasively invade and contaminate the survivors daily life. The longer the story remains untold, the more distorted it becomes in the survivor's conception of it, so much so that the survivor doubts the reality of the actual events."

Silence helps only the perpetrator, protecting them from being called out and the problem addressed. The power of story, of telling our stories for the world to hear, is that it is an act against silence, an act of empowerment.

I had kept my husband's violence a secret to protect him from what others would think if they knew what was happening behind closed doors at our house, to avoid stigmatization and to keep alive the perception of having a perfect life. After all, I owned a home and had a handsome husband: surely it looked perfect from the outside, and it should have been. But it wasn't.

\footnotetext{
${ }^{4}$ Ibid.,p. 64

${ }^{5}$ Ibid.p. 64

${ }^{6}$ Ibid.,p. 64
} 


\section{THE STORY COMES, AFTER THE ACCIDENT, TO IDENTIFY THE BODY7}

Part of the purpose of telling this personal narrative was to speak the truth about a story kept hidden. To speak out in the face of silence is "an act of reverse discourse". This act of defiance can provide a way forward that is "central to our understanding of autobiographical [...] personal narrative performance." 8

I had a strong need to bear witness to events of personal grief and victimization despite my fear and shame. "By beginning to speak about it, we may begin to threaten its continued, unacknowledged presence." ${ }^{9}$ My struggle with being continually censored within my marriage created a vulnerability that impacted the way I felt about myself in the world. In making this film I aimed to put that struggle outside of my psyche and assign the burden of it to the perpetrator. Still, it is not my intention to publicly shame my daughter's father, or add to her difficulties, so I have no plans to share this film openly online.

Felman and Laub points out that "performing testimony... is a highly complex act that is at once private and solitary, and on the other hand, public and communal and full of risk." ${ }^{10}$ There was a risk in telling my story, that it would trigger further aggression and reprisals, but I felt that if I didn't find a way to process my pain, I would permanently lose control of the chance for a positive and healthy future.

\footnotetext{
7 Craig Gingrich-Philbrook, "What I 'Know" About the Story"

8 Park-Fuller, Linda M. Performing Absence: The Staged Personal Narrative as Testimony. Text and Performance Quarterly. Vol. 20, No. 1, January 2000,P.22

${ }^{9}$ Survivor Discourse: Transgression or Recuperation? Author(s): Linda Alcoff and Laura Gray Source: Signs, Vol. 18, No. 2 (Winter, 1993), pp. 260-290 Published by: The University of Chicago Press Stable URL: https://www.jstor.org/stable/3174976

${ }^{10}$ Felman, S., \& Laub, D. (1992). Testimony: Crises of witnessing in literature, psychoanalysis, and history. Florence, KY, US: Taylor \& Frances/Routledge.. P. 263
} 
I chose to use poetic response rather than allowing silence to swallow me up. My pain was inescapable, feeding fears and growing dark, I needed to get rid of it.

I decided to face the risk and move towards a better future, to regain my dignity. This act of telling allowed me to stop suffering, process my pain and regain my self-confidence. "One has to know one's buried truth in order to be able to live one's life. $\{\ldots\}$ The "not telling" of the story serves as a perpetuation of its tyranny [as] silence is a place in which none find peace" and thus "unimpeded by ghosts from the past against which one has to protect oneself." ${ }^{11}$ I moved forward in life.

Professor Cathy Caruth, presently teaching at Cornell and previously at Yale, states in her work Trauma: Explorations in Memory, that "Psychic trauma involves intense personal suffering, but it also involves the recognition of realities that most of us have not begun to face." 12 The traumatic event can return as "repeated imposition as both image and amnesia, the trauma thus seems to evoke the difficult truth of a history that is constituted by the very incomprehensibility of its occurrence." It's a kind of amnesia, as she describes through the writings of Pierre Janet who proposed that is difficult to confront due to "its unexpectedness or horror"13 These flashbacks are "a history that literally has no place, neither in the past, in which it was not fully experienced, or in the present, in which its precise images and enactment are not fully

\footnotetext{
11 Ibid. P. 79

12 Caruth, Cathy. Trauma: Explorations in Memory. The John Hopkins University Press. London. 1995. Preface vii.

${ }^{13}$ Ibid. P.153
} 
understood $[\ldots]$ for the survivor of trauma, the truth of the event may reside not only in its brutal facts, but also in the way that their occurrence defines simple comprehension."14

As an individual who had been struggling to comprehend my reality, why this happened, how I could stop reliving it, I needed to find release. I came to understand that to heal from my trauma, I had to process the experience outside of myself, so I could gain perspective and ultimately, find closure.

Caruth writes of the benefits of using story to shift memory "the trauma thus requires integration, both for the sake of testimony and for the sake of cure... the transformation of the trauma into a narrative memory that allows the story to be verbalized and communicated, to be integrated into one's own, and others', knowledge of the past, may lose both the precision and the force that characterizes traumatic real."15

Producing this film allowed me to speak out, take a stand, reassess my beliefs and recreate myself. Tami Spry, who practices personal narratives around identity politics states that "the process of generating and performing autobiography offers me the power to reclaim and rename my voice and body privately in rehearsal and then publicly in performance." 16

Professor Linda M. Alcoff in her article The Problem of Speaking for Others writes about the necessity of empowerment in creating her own narrative work: "In speaking for myself, I

\footnotetext{
${ }^{14}$ Ibid. P. 153

15 Ibid. P.153.

${ }^{16}$ Miller, Taylor, and Carver Voices Made Flesh: Performing Women's Autobiography.Univ of Wisconsin Press, 2003 p.169.
} 
(momentarily) [...] create a public, discursive self, which will in most cases have an effect on the self-experienced as interiority" 17 Within the practice of Personal Narrative, the act of selfcreation "realizes a personal power - a power that not only provides therapy for the teller, but can affect audiences as well [...] as a healing experience"18

As much as I didn't want to admit to myself, there was continual ongoing low-grade violence happening in my home daily. It wasn't the kind of violence where I was physically injured, it was a kind of psychological violence that an outsider wouldn't see. Incidents would happen often and unexpectedly over mundane interactions, he would fly into a rage, lose control physically, punching up inanimate objects around me but never physically harming me.

Often, I'd be confused over what caused it. Because we were married, when I called the police to report these incidents, I discovered there was nothing that could be done from a legal perspective to protect me.

When living within this environment I spent my day walking on eggshells, afraid of what might come next. The behaviours I was living with felt similar to what I could imagine living with someone who had returned from war would be like, unpredictable and dangerous. My husband had become vastly different from the person I thought I had married. In my attempt to understand these behaviours, and why my marriage broke down, my research revealed PTSD

\footnotetext{
${ }^{17}$ Alcoff, Linda. The Problem of Speaking for Others. Cultural Critique. No. 20. Winter 1991-1992. University of Minnesota Press. 10.

${ }^{18}$ Park-Fuller, Linda M. Performing Absence: The staged Personal Narrative as Testimony. Text and Performance Quarterly. Vol. 20, No. 1, January 2000, P. 26.
} 
(post-traumatic stress disorder) is associated with an elevated risk of IPV (intimate partner perpetration ${ }^{19}$.)

"In the context of intimate relationships, individuals with PTSD may be apt to misperceive ambiguous partner behaviors as indicating probable social threat (e.g., rejection). Such misperceptions could increase hyperarousal, which impairs adaptive reappraisal of social cues and inhibits one's ability to control aggressive responses (Chemtob et al., 1997). Preliminary research suggests that later-stage deficits in social information processing (i.e., misattribution of partners' behavior to partners' negative intentions, decision-making in response to negative marital interactions) are important in the link between PTSD and male-perpetrated IPV (Taft, Schumm, Marshall, Panuzio, \& Holtzworth-Munroe, 2008)." ${ }^{20}$

\footnotetext{
${ }^{19}$ Marshall, Panuzio, \& Taft, 2005; Stuart, Moore, Gordon, Ramsey, \& Kahler, 2006. P.301

${ }^{20}$ Sippel \& Marshall. Journal of Anxiety Disorders. Posttraumatic stress disorder symptoms, intimate partner violence perpetration, and the mediating role of shame processing bias. The Pennsylvania State University, University Park. P.43
} 


\section{DOCUMENTING DAILY LIFE}

For my film I used mixed visual sources. I have always documented the world around me, from the day I picked up a camera as a teenager. I have always shot the important moments within our family, and of all the people I know. This story could have been several hours long had I not focused the story on this one struggle.

At a certain point everything clearly fell apart. I decided to go to a friend's cottage. Unable to sleep due to being upset, every night when the rest of the world was in its happy slumber, I would shoot time lapse sequences to soothe myself through creative expression. I had no idea it would become part of my film until I started going through hard drives and rediscovered the footage.

I used beauty to draw in the viewer and keep them engaged. At the same time, I used beauty to heal myself. I was living inside pain, at the same time creating images of beauty as a form of self-therapy to deal with my pain. The pain came out later, coincidently at the time I created this film.

For myself I find great value in photography as a therapeutic activity. Since I was a teenager, I've always used photography as a form of self-therapy, which is why I have always documented the world around me with vigor. 
In the article, Photography as Therapy, Craig Cosden and Dwight Reynolds state that photography in and of itself can be seen as a therapeutic activity. "It is our contention that if a picture is worth a thousand words, the procedures involved in taking that picture also have great value. $^{21}$

I chose the approach of using beauty to mask pain since in real life I'd kept the true conflict of my life a secret and covered my social media and social life with moments of happiness and beauty. For five nights I shot time-lapse sequences of 2200 to 2800 frames over a four to sixhour window, depending on battery life and how long I could stay awake. Three images from the time-lapse were chosen for large scale reproduction and hung on the gallery wall at the final exhibition of my work at the Black Cat Showroom on June 15th, 2019.

It has always been impossible for me to put down the camera. Shooting is the one thing that consistently brings me joy, as it is a meditation in motion, and I feel like I'm flying, or invincible on some level, when I'm shooting.

${ }^{21}$ Cosden and Reynolds. Photography as Therapy. The Arts in Psychotherapy, Vol. 9 pp. S-23, Ankho International Inc., 1982. Printed in the U.S.A. 


\section{DOCUMENTARY RELEVANCE}

\section{DOMESTIC ETHNOGRAPHY}

Glad You're Here is a film that takes the viewer on a journey inside family life through my eyes. It is a portrait of my life, and those around me.

Using real people to tell their story has been practiced by documentary filmmakers from the start, but autobiographical cinema is a relatively recent development within the genre. One of the main influences on my film is the autobiographical filmmaker and anthropologist, Ross McElwee.

Sherman's March, a quirky feature film released in 1985 turned out to be a surprise hit that transformed Ross McElwee's career. It was created at a time when documentary films were not considered commercially viable. Originally intended to be a historical film about the American Civil War, it became an autobiographical documentary, with McElwee as the main character. The film's lead, "Ross," was a personal version of McElwee as a hopeless romantic, falling for any attractive woman that comes near him. The film follows his pursuit of a handful of women: a singer, a Jewish lawyer, an aspiring actress, among others. It is the story of the way that romance mixes with the everyday that strikes a deep chord of truth with the viewer, that makes us "fall" for McElwee, the way we would for someone that was a part of our daily existence. It is the mundane, "the all too familiar rather than the exotic that holds sway."22

\footnotetext{
${ }^{22}$ Renov, Michael. Domestic Ethnography and the Construction of the "Other" Self. The subject of Documentary. Minneapolis: University of Minnesota Press, 2004. P. 218.
} 
This type of autobiographical practice, though different from my own, showed me a path forward for my work. By bringing the camera into my life, as I had comfortably done for years due to my personal need to remember and see through a lens, a level of closeness and intimacy is revealed. Like McElwee, I share the world around me as it unfolds; it's a self-examination without objectivity, for "there can be no pretense of objectivity" ${ }^{23}$ when observing your existence.

For the additional footage shot specifically for Glad You're Here, I explored multiple options, interviewing witnesses of my story, visiting sites of memory, always playful and serious, open to experimenting with modes of inquiry. Once I decided to reveal certain aspects of my story, I put off drawing the line between my personal and public spheres. I felt free to shoot everything and everyone, knowing the decisions about what to reveal would happen in the edit suite.

From my nineteen-year archive, I chose short, warm, happy moments to give context to what family life was like, but not so many as to exploit the subjects. I employed a grid formulation in the film to purposefully give the story context without exploiting family members in full-screen images that would have allowed a more direct, magnified examination by viewers.

${ }^{23}$ Ibid. P. 218. 

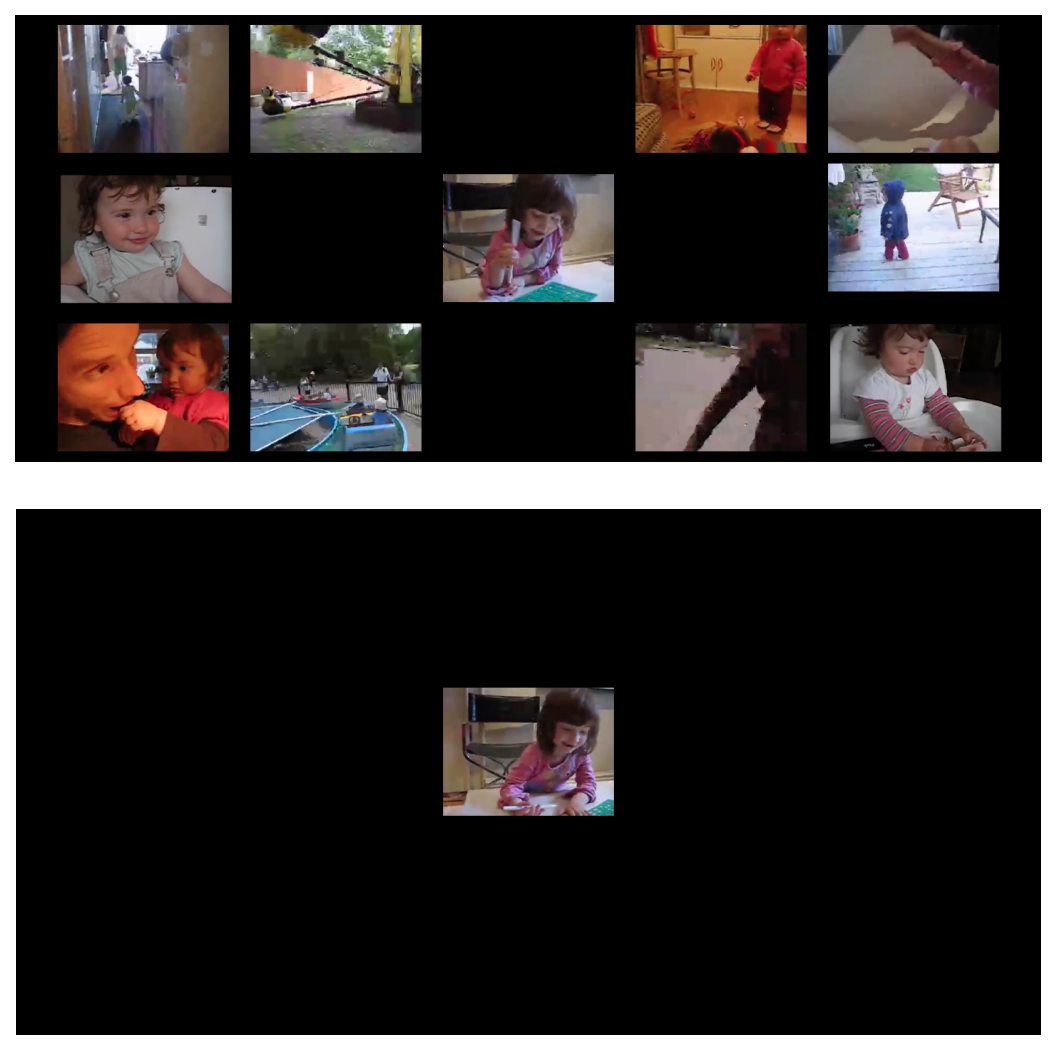

In the first instance, we see one small box in the middle, then a group of four surrounding images pop up one at a time. There's a family moment with my daughter as a toddler contained in each box. The grid grows to include another four boxes, then several more. The small size of each box allows a distinct sense of historical context without singling out one character or moment. Collectively they tell a story much stronger than any single moment would tell together. This is a story of innocence lost.

I decided to combine these moments and share as much information as possible in the shortest time to give context while also protecting my family. I didn't show darker moments for which I have images of violence in my archive. I chose happy moments when I could. I showed my daughter on the swings being pushed by her father, not the furniture he broke with his fists, nor 
her dollhouse after he kicked it in a fit of rage. I didn't share the pictures of blood in Pizza's kitty litter box after I found him half dead on the floor. I chose to create distance where I could, and reveal only what felt appropriate, with full knowledge that there will be a day in the future when my daughter will view this film.

When I used footage of my daughter interviewing me, I gave her an authorial voice. She did not have decision-making power in the creation of this film, but it was important to use this footage because it gave her some agency within our story.

Michael Renov, professor of Critical Studies at the USC School of Cinematic Arts, discusses the Domestic Ethnography film genre as one that engages in the documentation of people whose lives are intertwined with the filmmaker through blood ties. “...this mode of documentation takes as its object the father, mother, grandparent, child, or sibling who is genetically linked to the authorial subject." 24

It is a complex issue to represent your own family on film and share it in the public sphere. "For the Domestic ethnographer, there is no fully outside position available. Blood ties effect linkages of shared memory, physical resemblance, temperament, and, of course, family-forged behavioral or attitudinal dysfunction toward the artist - through her work - can fashion accommodation but no escape." ${ }^{25}$ By exposing my family I am equally exposing myself, through a kind of selfexamination, to better understand myself but I am also opening my family up to vulnerability and scrutiny. I say, family, even though I am currently divorced from my daughter's father; he is

\footnotetext{
${ }^{24}$ Ibid. P. 218

${ }^{25}$ Ibid. P. 218.
} 
always her dad, and therefore always a relation on some level. I am accountable to everyone that I point my camera at, whether progenitors and progeny, friend or foe. My quest for selfknowledge does not remove my responsibility as a documentary filmmaker to protect my subject. I am only able to refract a self-image with the participation of the familial other.

Filmmaker Su Friedrich's Sink or Swim (1990), a portrait of a father who abandoned his family is considered a willful act of historiographical revisionism, yet their fate is always intertwined. The film was therapeutic for Friedrich to create, and yet always "like analysis, remains interminable, always unfinished." 26 He will always be her father, alive, dead or absent.

${ }^{26}$ Ibid, p. 222 


\section{DOCUMENTARY PRACTICE FOR CHANGE}

The National Film Board's Challenge for Change program, which ran from 1967 to 1980, was a turning point in Canadian culture and documentary filmmaking where the personal became political. Using small portable cameras to document the world of the subjects, the filmmakers provided an outsider's perspective on the lives of their subjects. Two fine examples are Colin Low's one-take profile of a departing Newfoundland fisherman Billy Crane Moves Away and Kathleen Shannon's collaboration with then-singer and single mother Alanis Obomsawin, Our Dear Sisters.

Starting in the 1980s, the personal autobiographical narrative documentary emerged as a new genre. Two artists who work in this new form of documentary that I admire are the celebrated French filmmaker Agnes Varda and the American film director, writer, editor and actor Jonathan Caouette.

In The Beaches of Agnés, filmmaker Agnés Varda takes us by the hand on a journey through her life, to her favourite places, disregarding traditional norms of filmmaking to show us her quirky creative way of being in the world. She takes the viewer to sites of memory, retelling her story through poetic language, speaking playfully with the viewer, interviewing friends and collaborators, providing the narrative to her own story that can be shared for time indefinite. The Beaches of Agnes was shot while Varda was in her late 80s, in the last few years of her life, and is a reminder that we can be in control of our own story. 
Jonathan Caouette's film Tarnation is a film about personal trauma with similarities to my film. It is a search through personal archives to find answers in the past. Collecting decades of home movies and videotapes, answering machine messages and family snapshots, the film documents both the mental illness of Caouette's mother, Renee and the filmmaker's own early recognition of his homosexuality. The pair's survival in an atmosphere of pervasive abuse, addiction and abandonment are balanced by Caouette's stable adult relationship with his caring boyfriend.

I made my film to create positive change in my own life. I also intended to help others by telling my story. After coming forward, I have heard from countless others who have lived similar experiences of spousal abuse. Together we remove the stigma surrounding domestic violence.

The topic of domestic abuse was a part of my marriage I did not want to share in the public sphere. It felt like an embarrassment, a failure that changed my psychological state so much that I could not function as I once had. I lost my place in the world when I lost my home and the Belljar Cafe, the business I had worked for so many years to make. The cafe gave me power: a place to be creative and an audience to share that creativity. I created a community of people by being the face behind the counter, welcoming people in. I built an entire world there: an ongoing photo lecture series and monthly music events that I filmed and posted online, which brought people from all over the planet into the cafe. I welcomed book launches, birthday parties, film screenings, pop-up events. The place was always hopping. I wanted the Belljar to feed my family and pay my bills so I could focus on doing my photography. When it was gone, I lost my place and sense of confidence in the world. I felt defeated, especially as my husband continued to 
attack me. Violence from an intimate partner completely dismantles a person from the inside out, or at least that is how I felt. Just plain defeated.

Returning to university to study Documentary Media represented a certain level of activism that I knew I deeply needed. I needed to tell this story. I didn't know how, but I needed to make a positive change in my world so I could heal and move forward, back to that place of creative power, the seat I had once held, that made me feel deeply alive. 


\section{EMPOWERING SILENT VOICES}

One voice that took up the reins for social change was Suzanne Lacy, a performance artist inspired to go beyond the gallery walls by those who came before her: "Our mentors, like [Allan] Kaprow and [Judy] Chicago in my case, gave us the notion of working across platforms: the international conference circuit, working outside of museums, in alternative spaces, working with what is now called site-specific art." 27

Lacy was a founding voice in the Take Back the Night movement. In 1978, with the intention to develop community and political awareness, Lacy and collaborator Leslie Labowitz created Take Back the Night (TBTN), a mass public performance involving 3000 women marching in protest through the pornography district of San Francisco. In the same year, a similar march was held in Vancouver; growing from there, it turned into a global movement of annual Take Back the Night marches held in communities around the world. Speaking loud and clear through social media to quickly share and communicate as part of what we now call \#MeToo, victims of sexual crime who were previously silent now have a voice.

Lacy's perspective on feminism represented "an aspect of [the] larger set of social justice and equity concerns." ${ }^{28}$ Her philosophy was to connect people and face issues head-on, creating grounds for discussions which lead to change. Throughout Lacy's career, she took documentary art further; creating opportunities for real change by incorporating art into real life, directly

\footnotetext{
27 Bowers, Andrea. Lacy, Suzanne. Buszek, Maria Elena.Necessary Positions" in Feminist Art: A Conversation. Art Journal. Vol. 71, No. 1 (Spring 2012), p. 149. Published by: College Art Association. Stable URL: http://www.jstor.org/stable/23279675 28 Ibid., p. 148.
} 
involving opposing groups to create dialogue, and presenting projects to the public in various ways, including television news, video and interactive theatre.

Using the same tools as Challenge for Change, community involvement and connecting decision-makers directly to the participants, Lacy's work resulted in increased public agency, knowledge and perspectives. Her method of bringing together opposing groups to speak about their issues in public and broadcasting them through television and news coverage is an approach that has changed the way groups are represented and view each other, publicly and privately. Her approach was simple: get people talking, and those that aren't in the room can know about it thanks to television, print media, and radio. Open media platforms like YouTube, Twitter, Instagram and Facebook create a space for rapid personal communication and access to information, and as a society, we now communicate with more weight on the voice of the individual, in all its diversity.

It was on a Sunday afternoon in October 2017 that actress Alyssa Milano used her Twitter account "to encourage women who'd been sexually harassed or assaulted to tweet the words \#MeToo. Within 24 hours, a spokesperson from Twitter confirmed, the hashtag had been tweeted nearly half a million times. "With that, women (and some men) decided to break the silence about sexual harassment and abuse, igniting what activist Tarana Burke, the founder of Girls for Gender Equity, had begun over a decade before. ${ }^{29} "$

\footnotetext{
${ }^{29}$ Gilbert, Sophie. The Movement of \#MeToo: How a hashtag got its power. Oct. 16, 2017. Culture. https://www.theatlantic.com/entertainment/archive/2017/10/the-movement-of-metoo/542979/
} 
The \#MeToo movement has created an opportunity for women and men to use their voice and make a difference, standing in support of each other to raise awareness of the ongoing issues of sexual coercion, intimidation and violence. One person's choice to speak out instigated a mediadriven documentary movement involving millions of voices, creating the space and opportunity for real positive change. The audience for that initial tweet became the subject, creator and community and the force behind meaningful social change.

As a symbolic reclaiming of the right to move freely through the world without sexual harassment, the Take Back the Night movement encourages survivors to speak out and "shatter the silence" by gathering in communities and speaking as a group: "These events symbolize the importance of taking care of each other and creating a culture and environment where no one has to worry as they walk." ${ }^{30}$ It took four decades and thousands of women, men and families walking the streets in solidarity at TBTN events to make the \#MeToo social media movement possible.

As a result of the \#MeToo movement, I have come to see real world changes in my daily life. Recently, while working on an IATSE 873 union film as a scenic painter. During the weekly safety meetings, involving all production crew, the sexual harassment policy was verbally read aloud, clearly explained along with the confidential reporting policy and dismissal penalty for any crew members that chose to ignore the guidelines. This dialogue had not taken place at any point during my 15-year experience of working in the film industry.

\footnotetext{
${ }^{30}$ Ayalin, Marc. Navy Families Take Back the Night for Domestic Violence, Sexual Assault Awareness; Sembawang, Singapore. U.S. Department of Defense Information. 2016.
} 


\section{REPRESENTING TRAUMATIC EXPERIENCE}

Ari Folman's Waltz with Bashir (Israel, 2008), an animated autobiographical documentary, examines how to relate to a difficult personal history through the mind of the traumatized victim. The artist created the work as a way to process and understand his past and take authorship of his history, in order to have a way forward in his life. He was haunted by flashbacks, just as I was. For him, it was packs of angry dogs chasing him through the street, in his dreams. A repeated dream, a traumatic memory that woke him at night. Just as I was awoken in the night with flashbacks from my past.

Narrated as a stream of consciousness, the inner voice of Folman guides the story as he uncovers his suppressed and denied memories. Using formal strategies that are "largely unfamiliar within the language of the animated documentary Folman creates an otherwise visually inaccessible past, bringing the audience into a first-person experience, in a way that other modes of filmmaking never could. Lushly animated in clashing shades of cobalt and orange, accompanied by a meticulous audio landscape comprised of 102 different sound channels (which also include wolves, lions and tigers ${ }^{31}$ ), the opening sequence creates an unmooring audio-visual spectacle that assaults the audience's senses, shakes them out of their comfort zone, and immediately immerses them in the film's world." ${ }^{32}$ As the film moves between dreams and reality, sanity and psychosis, the animation bridges cinematically "what must be shown and what cannot be represented," 33 tying moments in time together, creating a timelessness, or time of 'its own': in

\footnotetext{
31 Guillén, M (2009) Waltz with Bashir - Interview with Ari Folman. Twitch, 10 January. Available at http://twitchfilm.com/interviews/2009/01/waltzwith-bashirinterview-with-ari-folmon.php (5 Jan. 2011) Google Scholar

32 Landesman, Ohad. Bendor, Roy. Animated Recollection and Sectorial Experience in Waltz with Bashir. Vol 6, Issue 3, pp. 354. First Published September 9, 2011 https://doi.org/10.1177/1746847711417775

33 Ibid. p.354.
} 
the present while also existing in the past. This sense of authenticity and truth ${ }^{34}$ are the essence of the documentary according to Nichols.

In Folman's film, the animation functions as the signifier, which allows the filmmaker "to own his past in a corporeal but fantastic form". This process of reliving events, this re-enactment of the past, in which the audience, immersed in the experience of viewing, "knowing it is a reenactment," 35 is transported directly into the memory of the event, provides "the necessary awareness of a gap between past events and present re-enactment [...] of what was but is now, at the moment of signification, past." 36 resulting in a sense of fantasy, or something Bill Nichols describes as Fantasmatic Pleasure. It reconstitutes ${ }^{37}$ the power of the past event into the present moment while minimizing "the sting of that which is lost and cannot be retrieved"38

The fragility of memory described by Folman's friend and fellow filmmaker Ori Sivan early in Waltz with Bashir serves as an underlying theme throughout the documentary. He describes it as the mnemic contexture, the entanglement of reality and fantasy that is the fabric of memory. Inseparable from our experience of reality, it is the background structure that allows entities, relations and identities to become meaningful." 39

\footnotetext{
34 Nichols, Bill.(1998) The voice of documentary. In: Rosenthal A (ed.) New Challenges for Documentary. Los Angele: University of California Press. P.20.

${ }^{35}$ Ibid. p.77.

${ }^{36}$ Ibid. p.83.

37 Ibid. p. 82

38 Ibid. p.76

39 Landesman, Ohad. Bendor, Roy. Animated Recollection and Spectatorial Experience in Waltz with Bashir. Vol 6, Issue 3, pp. 353 - 370. First Published September 9, 2011 https://doi.org/10.1177/1746847711417775 p.355
} 
The use of re-enactments in Waltz with Bashir provides a space for "the work of mourning that cinema, and video make possible, ${ }^{, 40}$ serving as a site for the imbrication of past and present. The memory is reclaimed, and the historic moment is forever flavoured and owned by those individuals who witnessed the massacre, giving testimony to Folman's trauma, while exposing an otherwise forgotten history.

The alternative to animation in the film would be talking-head interviews and dramatized reenactments, which would be less effective. The use of animation gives us a sense of the inner journey and inner voice of the characters, taking us inside the story in an immersive way. This creative treatment turns on a different part of our brain, taking us to a place that doesn't exist the world of dreams. As the subject travels through the story, sharing his experiences, memories, thoughts and perceptions, the mind of the director brings the viewer to a time and place that no longer exists outside of the film.

By mixing visual and audio layers of the real and fantastic, Folman examines memory and the human experience in all its complexity. Creating a space for the audience to connect to an otherwise impossible reenactment, "a stream of consciousness, unconscious elements, dreams,[...] to serve as a vehicle for fostering a new relationship between the viewer and the documentary text." ${ }^{\text {41 }}$ Therein, the animated documentary functions as a source of "our own knowledge about reality and not as artistic signposts of that same reality. Particularly in the evocative mode, concepts, ideas, emotions and states of mind difficult to represent in live-action

\footnotetext{
40 Nichols, Bill. Waltzing with Bashir: perpetrator trauma and cinema. Studies in Documentary Film, 8:1. 2014. P.75. DOI: $10.1080 / 17503280.2014 .900954$

41 Landesman, Ohad. Bendor, Roy. Animated Recollection and Spectatorial Experience in Waltz with Bashir. Vol 6, Issue 3, pp. 353 - 370. First Published September 9, 2011 https://doi.org/10.1177/1746847711417775 p.354.
} 
imagery $[\ldots]$ thus broadening the epistemological potential of the documentary genre by expanding the range of what and how we can learn" ${ }^{\prime 4}$

The viewer gains a sense of how it feels to have lived through a traumatic event with the longterm effects of PTSD, which affects the way the mind functions and processes trauma. This theme is reinforced throughout the film as Folman seeks out and visits former soldiers from his dream. Each witness of the trauma holds a piece of the story but lacks the full details of their past, calling attention to the psychological dimension of trauma, its aftermath and the effects of PTSD on their lives.

\footnotetext{
42 Paul Wells, "The Beautiful Village and the True Village: A Consideration of Animation and the Documentary Aesthetic", in Art and Animation, ed. Paul Wells (London: Academy Group/John Wiley, 1997),40-45; Sybil Del Gaudio, "If Truth Be Told, Can 'Toons' Tell It? Documentary and Animation", Film History 9, no.2 (1997): 189-199; Annabell Honess Roe, "Absence, Excess and Epistemological Expansion: Towards a Framework for the Study for Animated Documentary", Animation 6, no.3 (2011): 215-230. Within Paul Well's taxonomy, Waltz with Bahir would seem to oscillate between his intervening artist "subjective" and the "fantastic" mode. Folman as director and animation director Yoni Goodman intervene as creative subjects to animate Folman's flashbacks in a taxi after his visit to Carmi Can'an, turning the landscape of the Netherlands into a Lebanon battlefield; on the other hand, the film's surrealistic imagery seems to fit into Well's fantastic mode, which accounts for what lies beneath the surface of everyday reality in animated documentaries. - quote from notes by Vassilis Kroustallis in article: Failure to Think, Failure to Move: Handicapped Reasoning in Waltz with Bashir. Jewish Film \& New Media, Vol.2, Fall 2014. PP.132-152. Wayne State University press, Detroit. MI 48201-1309.
} 


\section{METHODOLOGY}

\section{FINDING MY VOICE}

When I started this project, I met with my advisor Pierre Trembly, who encouraged me to think of this film as a series of chapters. The order of the chapters didn't matter--they would come together like a puzzle at the end (editing phase)--since the important thing was to develop my creative process. In this learning phase, content could be abstract or solid, a visual poem or a thought; I just needed to be as creative as I needed to be.

So, I let the work come out naturally, in a self-reflexive manner. The goal I had set for myself, he reminded me, was to use my work as a safe place that would ground and support me.

I felt encouraged to have fun, make work that felt right, that would be empowering and positive. The reality of my everyday life had been, for many years, filled with strife. I had been affected by the constraints of being a single mother in the middle of a divorce, with an aggressive angry, abusive and possibly bipolar or suffering from PTSD, ex-husband.

I was delighted when Pierre shared details about director Floria Sigismondi's creative process, revealing that she convinces herself that no one will ever view the work she creates in its early stages. Often, Sigismondi creates videos, photos and films for herself (though she also does commissioned work), and is able to separate from the sphere of public into a private space, removed from outside opinion. She is capable of mediating within a space deep within, without negativity or consequences: right or wrong, should or shouldn't. 
It is within this deep inner sanctum that the artist can find and use their true voice. Make note, this is my impression of the conversation I had with Pierre. I liked the inference that when I create work, I am only ever doing it for one person: Myself.

After Sigismondi creates the work she then decides if she will share it. Some pieces remain in the vault of the personal till it feels right to share it, if ever. The quality of the work that she makes public connects deeply with the viewer in an honest, gut wrenching way, due to its universal elements.

She went through this process over and over and built a career from it. In a recent interview she described her early process as an artist:

\section{"I learned to trust myself and my offbeat ideas. I had put myself through sleep} deprivation - some type of deep meditation without knowing it - and (started) manifesting ideas out of that state. It was a magical experience for me seeing the imaged ideas manifest into physical form."

"I was experimenting in the most rudimentary way, but it was a start to something much more sophisticated. ",43

\footnotetext{
${ }^{43}$ https://www.factmag.com/2017/10/11/floria-sigismondi-music-video-director-interview/
} 
I enrolled in this MFA program to find my inner creative voice; I had wanted to be a filmmaker since I was a kid. I would dream stories at night and in the morning when I tried to write them down, I couldn't. I couldn't read, and no one knew that I had a learning disability. No one in my house would cooperate when I asked them to write out my stories. I felt ignored, even stupid.

Growing into a teen, my academics improved dramatically with a specialized school, key learning tools and accelerated growth with one on one tutoring. I was encouraged to view my disability as a tool, which gave me a different approach to problem solving. I gained a whole new perspective on expression, and empowerment.

Being in the place in my life that I am at now, restarting after losing everything except my daughter, I decided I needed to find a way to tell my own story and process my traumatic experience. 


\section{ENTER: MY FILM}

When I signed up to make a film, I thought I wanted to tell the stories of others. I knew it had to be an honest story; about something with which I was intimately familiar. Since I was in denial on a certain level, I didn't plan to tell the story of the violent situation I had been living with for the past several years. That was not the film I intended to make. I felt that the story was too sad, that that I felt no one would like to hear it.

Repeatedly I would wake up in the middle of the night, sleepless, with a desire to write things out, having flashbacks of violence. I had an impulse to document what had happened, a need. Gradually a calmness took over and I gave it expression. I wrote on sheets of paper on my bedside table what had happened, and how I really felt about it.

I began to accept that what I had been experiencing were recurring flashbacks of living with violence, years after these events had happened.

I had been researching about PTSD for a class assignment in my archives and databases class, and the truth kept jumping out at me on the page. Memories were being triggered. They would come unexpectedly, and I could not get them out of my mind. At the exact time of the Ryerson program when I had to decide on a topic for my film, this is where my brain kept going.

The process of making the film started affecting how I was interacting with those around me. Many times, I felt like giving up the film and forgetting about it. Remaining silent. Moving on with my life. Letting go. Covering it up. But there were constant reminders every day in the 
world around me of what I experienced. Every time I touched my cat. Every time I opened an email from my divorce lawyer.

All the while, I was still living with regular verbal attacks from my ex-husband, on the street, in the cafe, always in front of my daughter or neighbours, or strangers. If I wasn't married to this person, I could have pressed charges, but the law is different if you're married. No one sees it for what it really is; ongoing abuse. These may seem like harsh words from the outside, but when you've lived it, it's the tip of the iceberg. It was hard to admit to myself, that so many horrible things had happened. Silence is a trap. No one around me knew and it was easier to stay silent than pick at the lock.

Creating the work that I presented in master class was probably the hardest thing I've done to date. I had no idea if I would have the courage, but I needed to try. I began to understand that my story wasn't about one incident of my cat getting kicked. It was about an ongoing history of living with violence. I had been in an abusive reality, a discovery I didn't face until I reached the editing phase of production. Just when I thought I was wrapping up my film (the one I had been sharing with the class for the full term), the true story was ready to be told.

Editing became a journey exploring nineteen years of memories in twenty-two hard drives. I discovered videos of loving moments as well as documents of violence within my home environment; broken dollhouses, furniture and appliances; smashed windshields and broken mirrors; pictures of my cat after the vet. Every image carried a painful reminder. It felt like smashing my head against a wall. The film was evolving as I examined and rediscovered home 
movie footage in my archive. I was falling backwards into my history, alone in my editing suite. So many tears! Revisiting moments that no one outside of myself would grasp the meaning of unless I created context.

I was experiencing deep inescapable grief; hours of tears, exhaustion in my heart at the end of each editing session. I stopped being able to sleep, waking up at 3 am with words needing to be written down, storylines to include in my script revisions. It was the perfect time to work, while the house was quiet when my thirteen-year-old daughter was asleep.

The emotional journey was unexpected; it brought with it a certain level of depression. I realized all that I had lost while living in deep poverty in an apartment I couldn't afford, taking time off from being gainfully employed to return to university to focus on a passion project, as my bank accounts ran dry and bills piled up.

It took some time, and then I decided it would be safe to speak. I chose to directly talk about my personal experience of living with domestic abuse. After a particularly long day in the edit suite, I came home, and I wrote this in my journal:

This edit reminds me of the day I had my daughter. I was in the bathroom at the hospital when I went into labour. I came out of the bathroom and tried to leave. Somehow when I was alone in that small room, when the pain started coming and was inescapable, I thought that the best thing to do was to leave the room, to leave the whole hospital in fact. I was so inside of the pain that I didn't even know the reality of what was happening to me. I couldn't see it. 
That's how it felt making this film. Looking back through my old hard drives, I was digging through footage I hadn't looked at since I shot it: all the bad things that had erased those happy moments, the feelings of love that were part of my everyday peaceful life. Revisiting those memories became a trauma and I started to break down and be so fraught with grief that I couldn't see where I was going. Why was I making this film? It became a daily battle to revisit these sites of memory. I felt such incredible loss, and then I'd open a new hard drive and the feeling would be compounded.

They say the editorial process is the hardest part of filmmaking, but it wouldn't feel near as hard if the footage I was sorting through wasn't my actual life. Images I shot, memories I had documented as a keepsake for a future that I'd felt was predetermined. Plans I made somewhere in my mind as I shot them, that these images would be deeply meaningful in a different way, shown at my daughter's wedding or at a home movie party, revisited in a place of joy, not of deep grieving. The years haven't slowed the pain though the sting is not as bad, though even now as I write this, I cry.

Despite the frequent, costly conversations with lawyers, a division of my assets with my-ex, a trust-fund kid who has hidden his assets, doesn't erase the deep love in my heart that I've lost the father of my child, and hence lost my family unit. The knowledge that my daughter will never experience the future I foresaw when I gave birth to her, the family life I had wanted since my own childhood traumas began, hurts me deeply. 
It took countless conversations with myself to begin and travel this journal. Here is what I wrote at 3 am in my journal:

How can we create a true portrait if we project ourselves upon the project? How can I make a document about my life without projecting my current self upon the story, can I be neutral? What is the point of telling the story if it is not true to the lived experience?

Empathy is the one and only job we have as documentary filmmakers. We put ourselves into the shoes of others and "get" how it feels to be them. If we can do this, it is a gift we give to the people whose lives we are filming. It is a gift I give to myself as I made this film. 


\section{TRUSTING THE EDITOR WITHIN}

I used Alex Anderson's rules of editing as a template throughout the post-production phase. None of my cuts were random; there was always a reason. I was paying close attention to timing, connecting story ideas together. I got really good at reading the audio wave files and stringing together sentences from interviews. I could make entire sentences that were never spoken, by paying attention to the intonation of the voice. None of those edits ever made it to the film though. I realized, in the end, I had to tell the story in my own voice, recordings made at the forty-eighth hour of sleep deprivation.

I had become meticulous and perfectionist, but it was working against me. I hadn't figured out my voice was missing. I'd edited scenes upon scenes, but I hadn't noticed the key problem with the work. I would examine each timeline to see where I could cut the extraneous information, but I had a hard time staying on topic.

I would cut a scene right after the footage made its point, judge how long to hold the moment, use the footage to find natural in and out points; cutting after walking through doorways or turning corners, fading to black at the point the footage was mostly black. I mostly cut without music but found that adding the music in once I was closer to a fine cut, gave me a tempo to cut to as I finished the film. It helped to make scenes longer that seemed boring, to give a spot for a breath. I also needed some optimism to turn off my brain, so I found music that wasn't as sad as I felt. 
I paid close attention to pacing. I wanted the information to come at a good speed to keep the viewer attached to the story, not wanting to pull away. Bring them into the character landscape, engaged.

I grew attached to certain moments; I wanted to use footage of my dog at the vet because I thought it was so much fun, but I remembered the negative feedback in class. The story was about the cat, so I opened the scene at that moment. I cut out the confusing parts of the recorded phone call with the vet's office, and the scene went from fifteen minutes to under four minutes. I started to become less rigid, less attached; started to see how the story could evolve.

Eventually, I decided against using those funny moments of the dog sliding across the medical table (clearly not wanting to participate in the vet appointment). I brought purpose to the audio recording of my conversation with the vet tech. The only reason for the scene was to communicate specific information, not my commentary on how cute my dog was. I had many versions of the timeline, which finally started evolving as I began to trust myself. Like a dance: one step forward, one step back, it began.

I had to cut out all the footage of my husband. It was never going to be ok to expose him for any reason. That would turn the film into a "trial by documentary", something that Alex Anderson warned me against. I wanted this film to be therapeutic for me. I can only affect my own life, not his. To use his footage would have been to point a finger and take the path of blame when mental illness (if that's what he has) is not a choice. The only story I have the right to tell is my own. 
I chose to only use images of my husband from when times were good when we were in public or in the presence of others. I videotaped photographic prints from my photo archive with rack focus, kept the cuts short to give relevant information without extra time for scrutiny. Placed those scenes sequentially so the story is happy when you see his image. We don't see his image again as the story grows darker.

I chose footage that showed myself so that I would be the one under the microscope. Someone had to represent this story, and I am the one that lives with it. I chose moments of my daughter when she was very young, and shared specific moments to carry the story forward and communicate what was at risk--the innocence that was lost. The film went from seventeen minutes edit to ten, to keep the issue at the forefront as much as possible.

But then, I started going in circles.

I felt I was getting stuck and I realized that I needed a neutral influence. Both of my advisors were out of the city, one in Montreal, the other in Finland. I needed an advisor who was in the country, who knew very little about my personal life or my project, someone with the mind of a poet. 


\section{ENTER: STEFAN MOREL, ADVISING EDITOR}

I reached out to Stefan, an artist I curated at Open Show (a monthly artist talk series held at the Belljar) several years ago. He is an experienced commercial director who edits his own work. A very serious, focused thinker, with strong boundaries around director ownership. He would not cut my film, even as I started to wish I could wash my hands and shrivel away. Stefan understood the difficult editorial process as a veteran, in a way a first-time filmmaker never could. He provided perspective at a critical phase, which took me to a more serious place within myself.

He taught me editing shortcuts but did not intervene or contribute to the editing process beyond viewing Vimeo links, then calling to give notes over the phone.

Stefan reminded me that "falling in love with an edit or a shot is every director's problem. It is a habit we all have, and we can't allow it to happen. The story suffers at the sake of this selfindulgent love affair an editor has with his edit. The choices must remain fluid in order to evolve."

He kept reminding me that I was earlier in the process than I realized. I didn't have the luxury of purely focusing on the edit due to having to juggle my real-world responsibilities of parenting: picking my daughter up from school, helping her with homework every night, making dinner, doing household chores and laundry; working as a freelancer shooting editorial assignments; shooting sixteen-hour weddings on weekends; scenic painting on films for my union, IATSE; photo assisting; and taking on any and every gig in order to cover the $\$ 2000 /$ month rent plus the 
$\$ 1000$ bills and loan payments, plus food and clothes for a rapidly growing young teenager and her sometimes very tired mother.

Prioritizing family time on weekends because I couldn't just stare at the computer when I had my thirteen-year-old daughter with me since her father takes her two days a week on school nights. Being a single mom, fighting the demons of divorce, costly legal meetings, responding to court action, preparing paperwork for the judge for the upcoming hearings--all super fun stuff to mix in with finishing an MRP paper and Thesis film.

I appreciated being reminded that I would never have the kind of time that I'd have received if this was my only job. I had to take the story down to its essentials; I could always add more down the line.

Once the extra bits of fat were removed, it was a completely different film than I had intended to create. I had started to speak my honest thoughts by using the same words I had been writing in the middle of the night on blank sheets of paper by my bedside, for months and months. My voice started to appear in the work.

I decided to trust myself. I opened my ears and only focused on the work with no distractions. If I was drowning, I could call out for help, but I had to do the work. It was my future at stake, my dreams.

I changed the title from Pizza, the stars \& lawyers, to Glad You're Here, after staring at a photo I had inserted into a previous edit. On the chalkboard at the café, I had written "Glad You're 
Here" to signal to potential customers walking past that this was a good place for them to discover. It was an expression of where the project was going. Given how the shape of the project was evolving into something different, the title had also evolved.

I got caught in a cycle of fear that lead to some moments of delay and self-sabotage. I spent time worrying about small petty details, kept falling into anger and sorrow. As things got harder, Stefan would remind (notes from our conversations):

"It is very difficult to do this type of work. Especially when it is your story, you become incredibly sensitive. It has nothing to do with ability as a filmmaker. I've been working as an editor for 20 years and I don't know if I would be able to tell this story if it was mine."

" Holding yourself back to be sure to check all the boxes that nothing is overlooked is putting you in a holding pattern. There are 10001 other moments that are equally important, but you have so little time, so much footage, you are harnessing yourself with an unnecessary burden. Let go of the commitment, take that twenty years of experience and condense it off the top of your head."

"A viewer won't care to see both sides of the story, they're not expecting journalism. This is a diary, a cathartic journey about turning the page and leveraging the past to move forward. There are no mistakes."

"What matters is that you created something with the cafe: a space, an idea, a vibe. You built it against all odds. You should feel proud. You have all the facts. Now turn those facts into emotion."

To have someone, anyone, take the time to read the piles of words I had distilled, to understand my stance, and how difficult it was to be inside of it all as I was learning how to speak it, was an incredible gift. Stefan, at precisely the right moment, provided a light at the end of the tunnel. 
"That brick wall will give way, I promise you if you continue working on the edit. Keep going."

- Alex Anderson, class notes.

In the eleventh hour, I had a full emotional breakdown / manic panic attack. I called my childhood friend Laurel. Crying, I told her I couldn't go on, that I was afraid. Afraid of what this would do to my daughter, of what my husband would feel. Afraid it was a mistake to speak the truth. She reminded me that it is never ok when someone hurts you, kicks your cat, breaks your stuff, manipulates and steals from you. That it was not my fault.

I had gotten so inside my head that I didn't realize I was not living in a marriage anymore, that I was separated and free from it all. That my voice mattered. All I was hearing in my head repeatedly was the sentiment of my husband, that he would be angry at me for making this project, for sharing his memories, for talking about what he felt justified in doing to me because he was my husband. In my head, I was still bowing down and accepting what he had done. I realized I had to let go. That what I had before me was a choice.

To go through loss is universal. Others had lived through this experience, as partners or witnesses. That I could offer solace to others, as my friend Laurel had done for me. No one has to go through the pain alone. This realization allowed me to go back into the editing suite and make choices that previously I had been unable to make. I trusted my gut and moved forward. 


\section{SELECTED RESPONSES}

\section{DANIEL LANOIS:}

Lisa

I just watched your film

You are brave and it's beautifully done

Daniel

\section{PAUL ROCHA:}

I sent an email to the music publisher to purchase music licensing for Plus Tot by Alexandra Streliski. I had several email exchanges with Paul Rocha, Director, Creative Licensing and Synchronization. I sent him the link to the film, and he wrote back almost immediately:

Hi Lisa, I appreciate your getting back to me and for sending over the information and the updated link to watch the film (which I found to be extremely moving and powerful). Being the child of a single mother who was in an emotionally and physically abusive relationship with my father, your film really struck a chord with me. There's something special about relating with a stranger on something so personal and difficult to talk about. I'm of the belief that we need to sometimes take a step back, assess things and have these tough conversations (when we're ready, of course). I find that when we have the courage to do that, we find our "people," those who have experienced something very similar and it allows us/them to have the confidence and comfort to speak up and out. It's empowering yet scary and I admire and respect you for doing that. 


\section{SCRIPT}

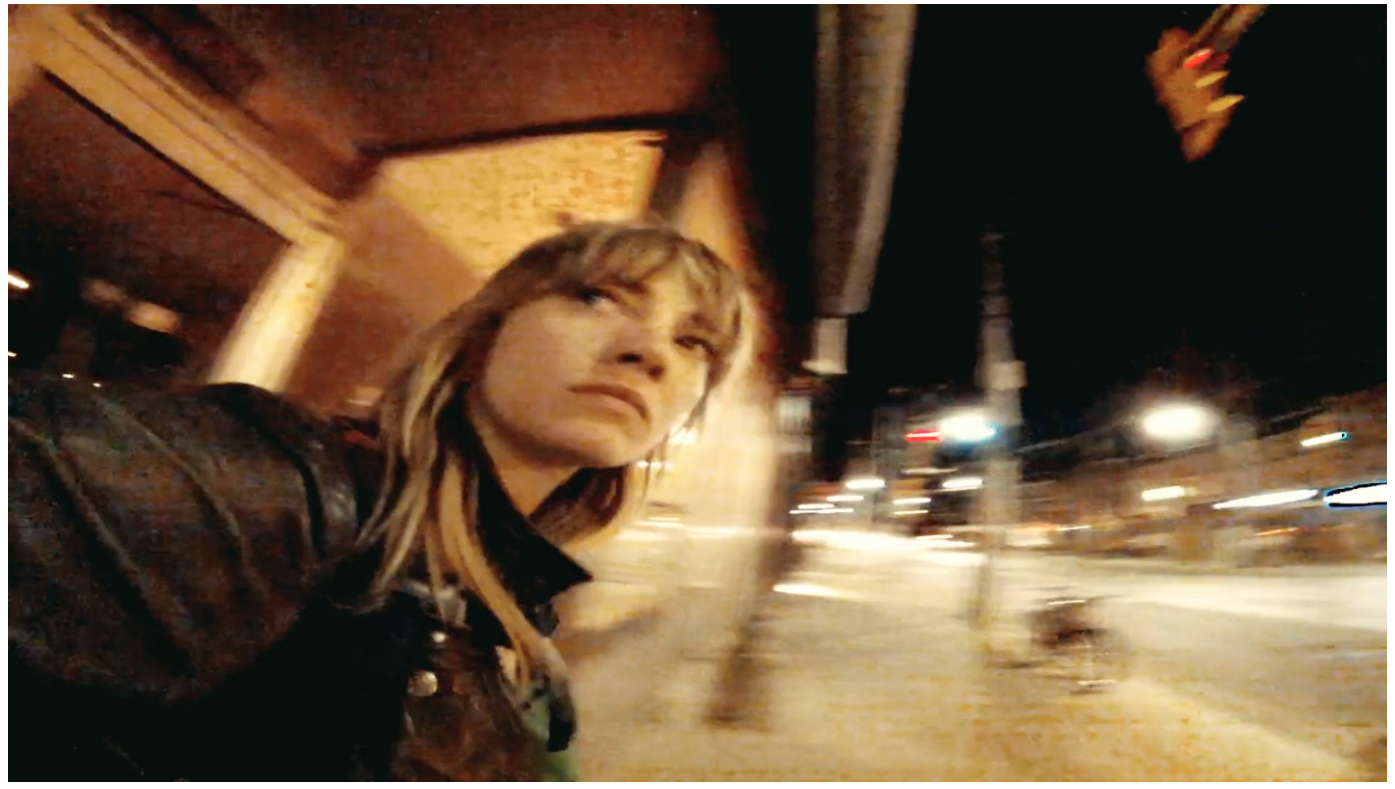

This is me. When I was a kid, I want to be a filmmaker. I would dream stories at night and in the morning when I would try to write them down I couldn't. It turned out I had a learning disability; I was far below grade average. I had faked it all those years to fit in

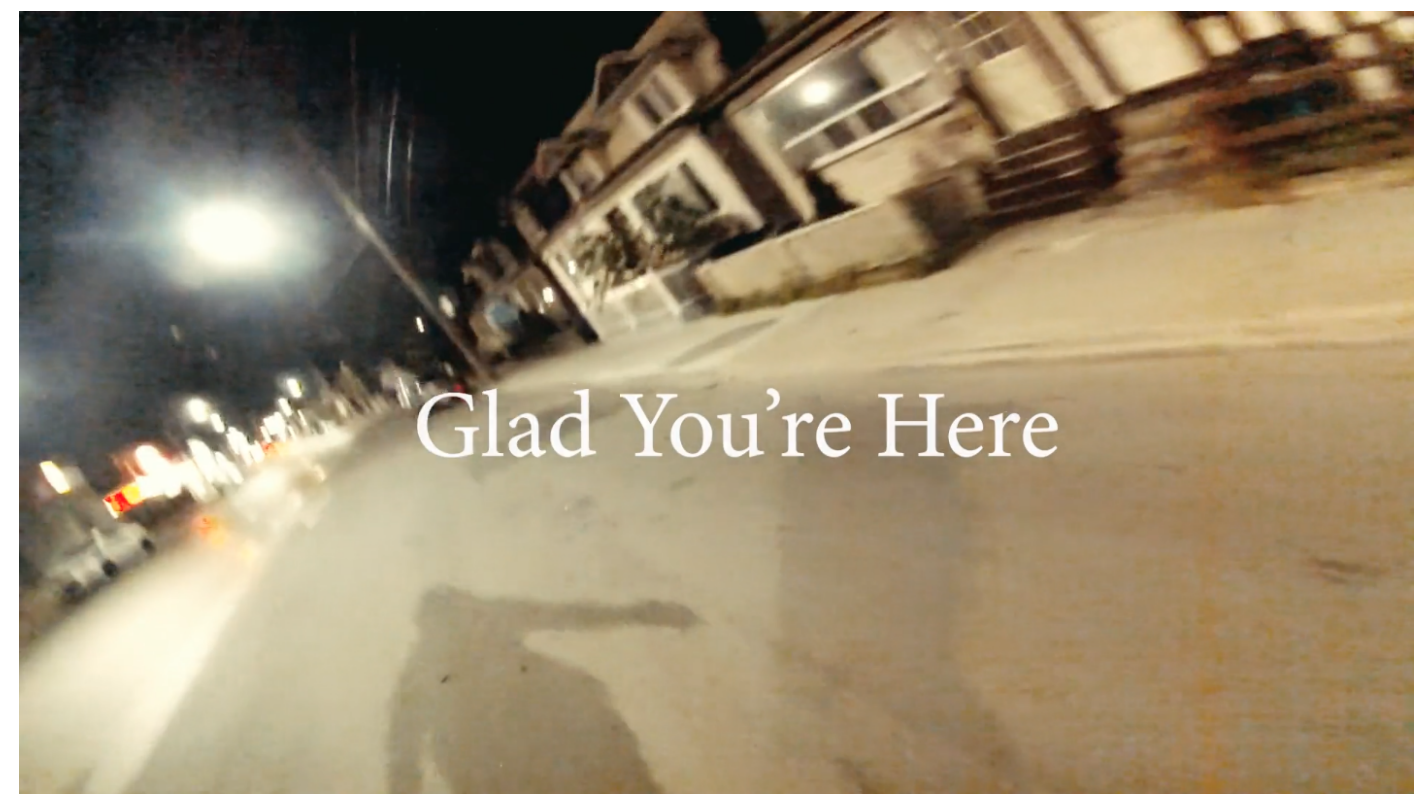


Daniel Lanios: This reminds me of the coffee houses I used to play at when I was a kid

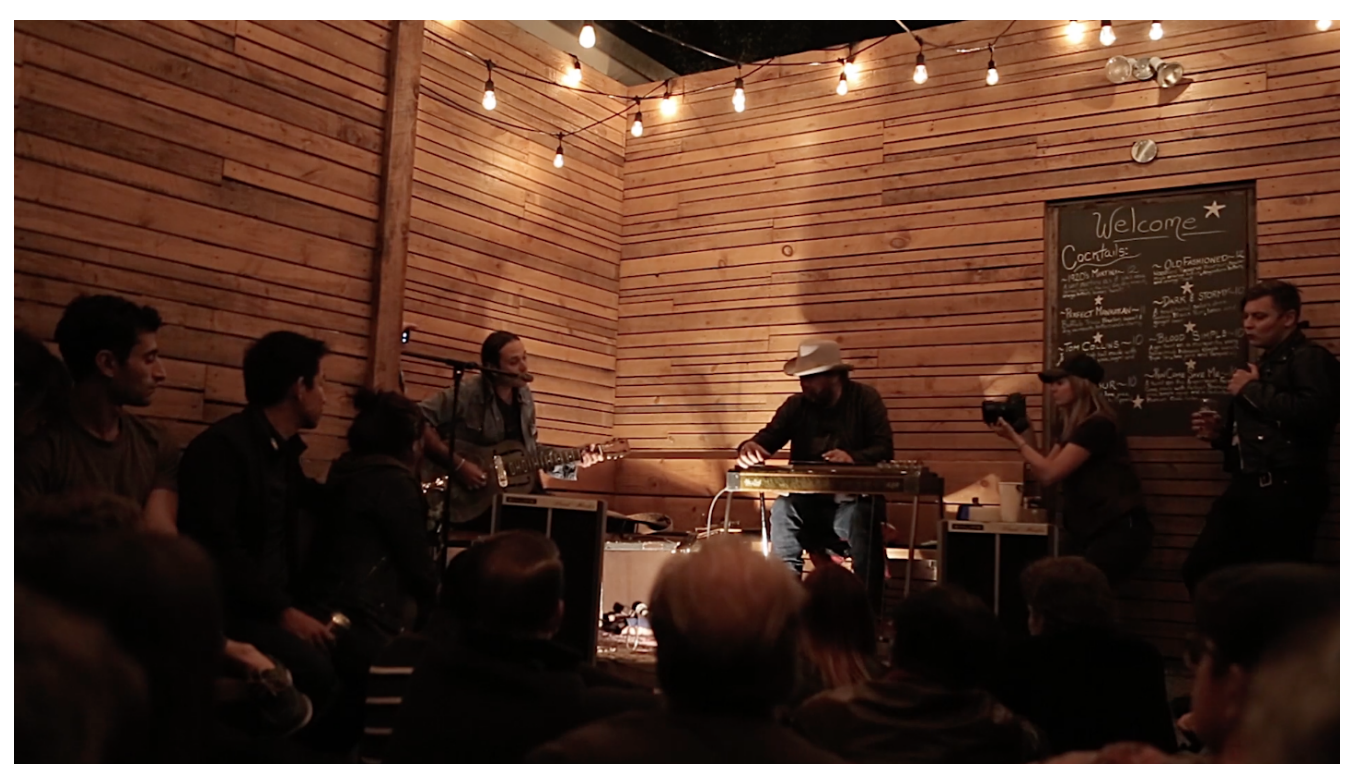

If you could see through the wall, you'd see my husband sitting inside drinking scotch, angry that I'm doing this. Everyone else is on the back patio watching the show as I film it. Later he would say that this was just one of the many ways I stole his limelight and walked all over his manhood

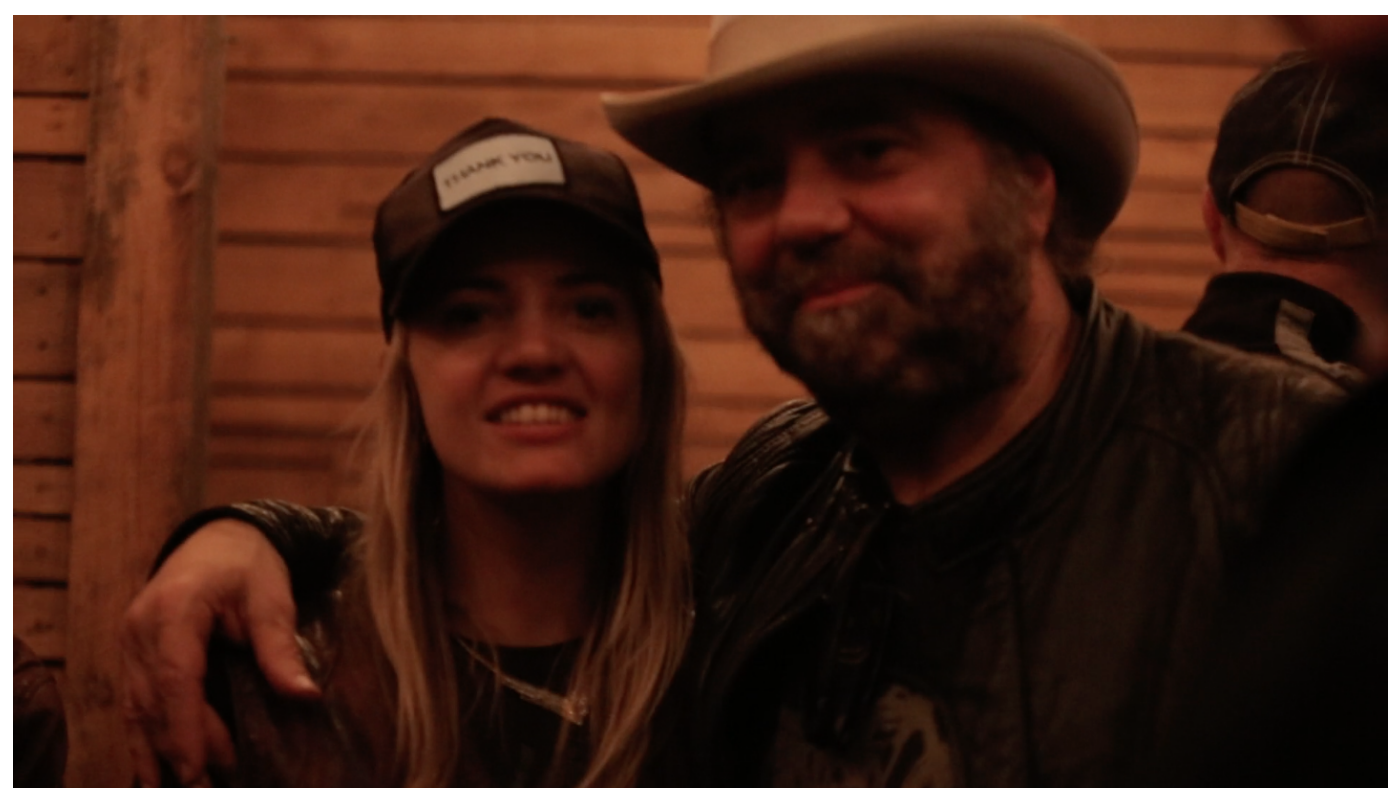


Sophia interviews me:

Lisa: $\quad$ Now you see that little red light, little red button? That means you're recording. Now you can ask me questions. It's called an interview, so point it at me.

Sophia: What's your name?

Lisa:

Mommy

Sophia:

Lisa:

What's your address

Sophia:

25 avenue, toronto

Lisa:

What's your house phone number?

Sophia:

Lisa: 416...0043. These are good questions

Sophia:

Lisa: What's your dad's name?

Ray

Sophia: $\quad$ What's your kids' names?

Lisa:

Sophia

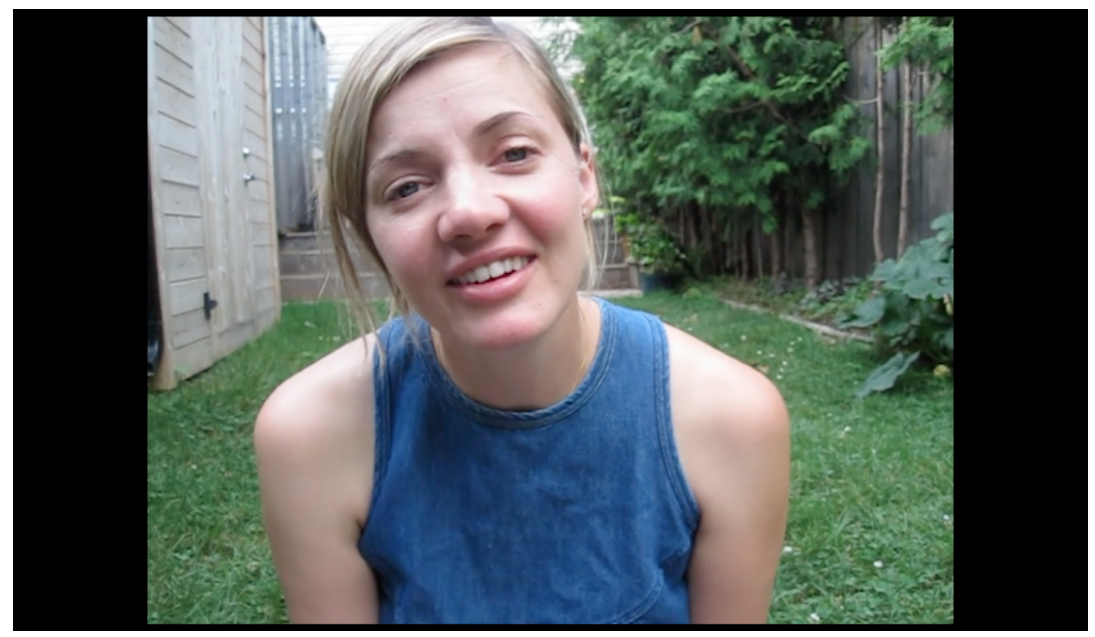

I met my husband through my friend Ruby. She had dated his brother, and he knew that we would be a good match. Falling in love with him felt right, felt like fate

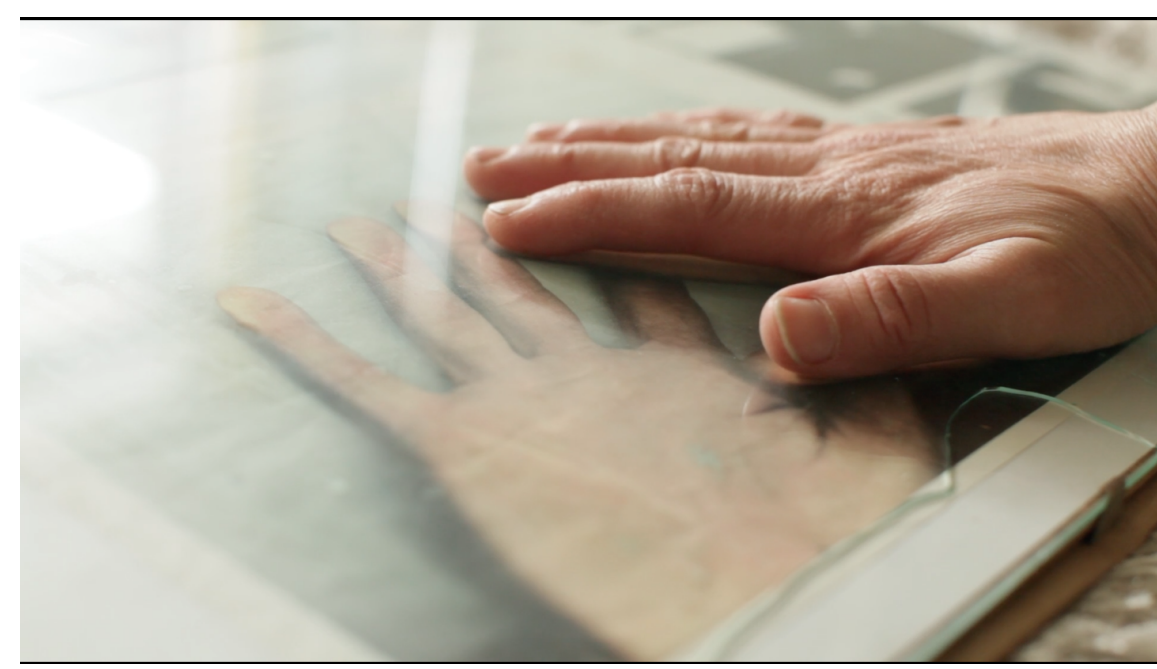


Years ago, I was in a car accident.

I received a cash settlement from insurance from my injuries and I bought a house

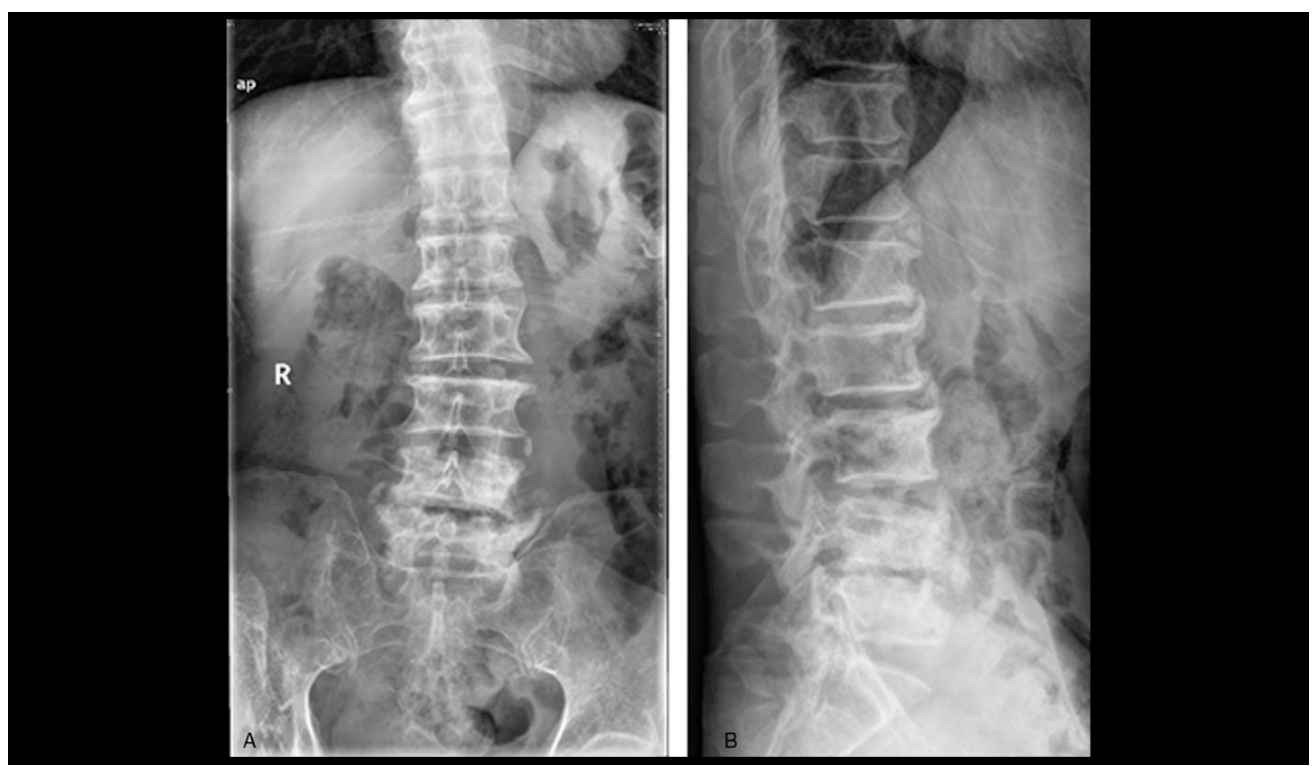

When my husband wanted to open his business, I jump in feet first. I remortgage my house so I could lend him the money and keep us afloat. He said my name didn't have to be on the incorporation paperwork, that since we were married everything was ours together, and I believed him.

I was running for the team to make it work, to support his dream and take care of our daughter.

I gave up my professional work.

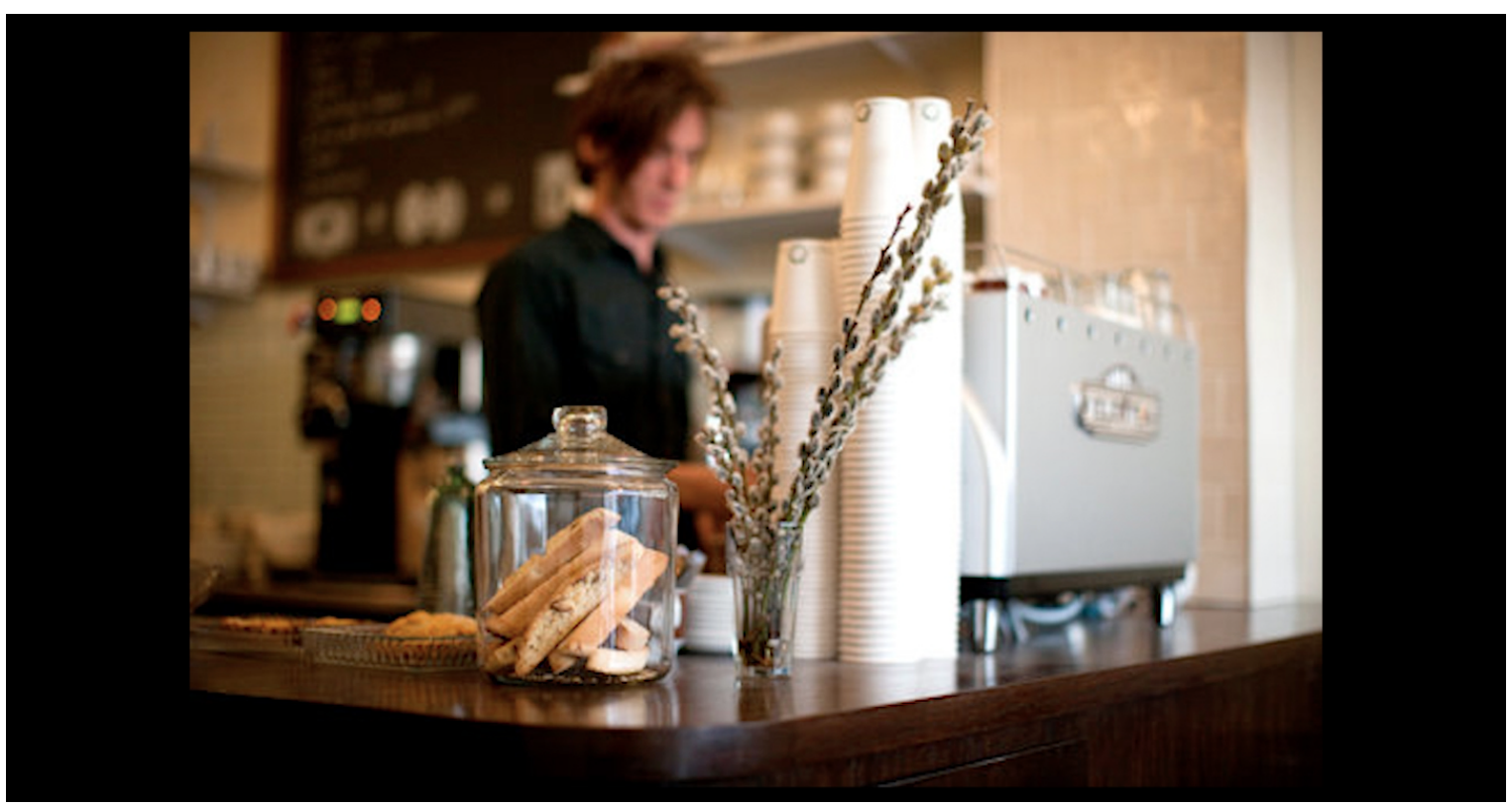

I invested my inheritance into the business 
Sophia sitting on me, I am filming her

Lisa: $\quad$ You just have to save those seeds until spring

Sophia: But where can I put them to save them?

Lisa: $\quad$ We can find a special spot

Sophia: $\quad$ I know where I have my special spot (runs into backyard)

Lisa: $\quad$ Maybe a special spot inside?

Sophia: $\quad$ Pizzajumped out! (Laughter)

Pizza jumped out.

Lisa: $\quad$ Yes

Sophia: $\quad$ Isn't that funny? Pizza jumped out of the bushes.

Lisa: $\quad$ Did he?

Sophia: $\quad$ Take a picture of this (holds bean in camera lens)

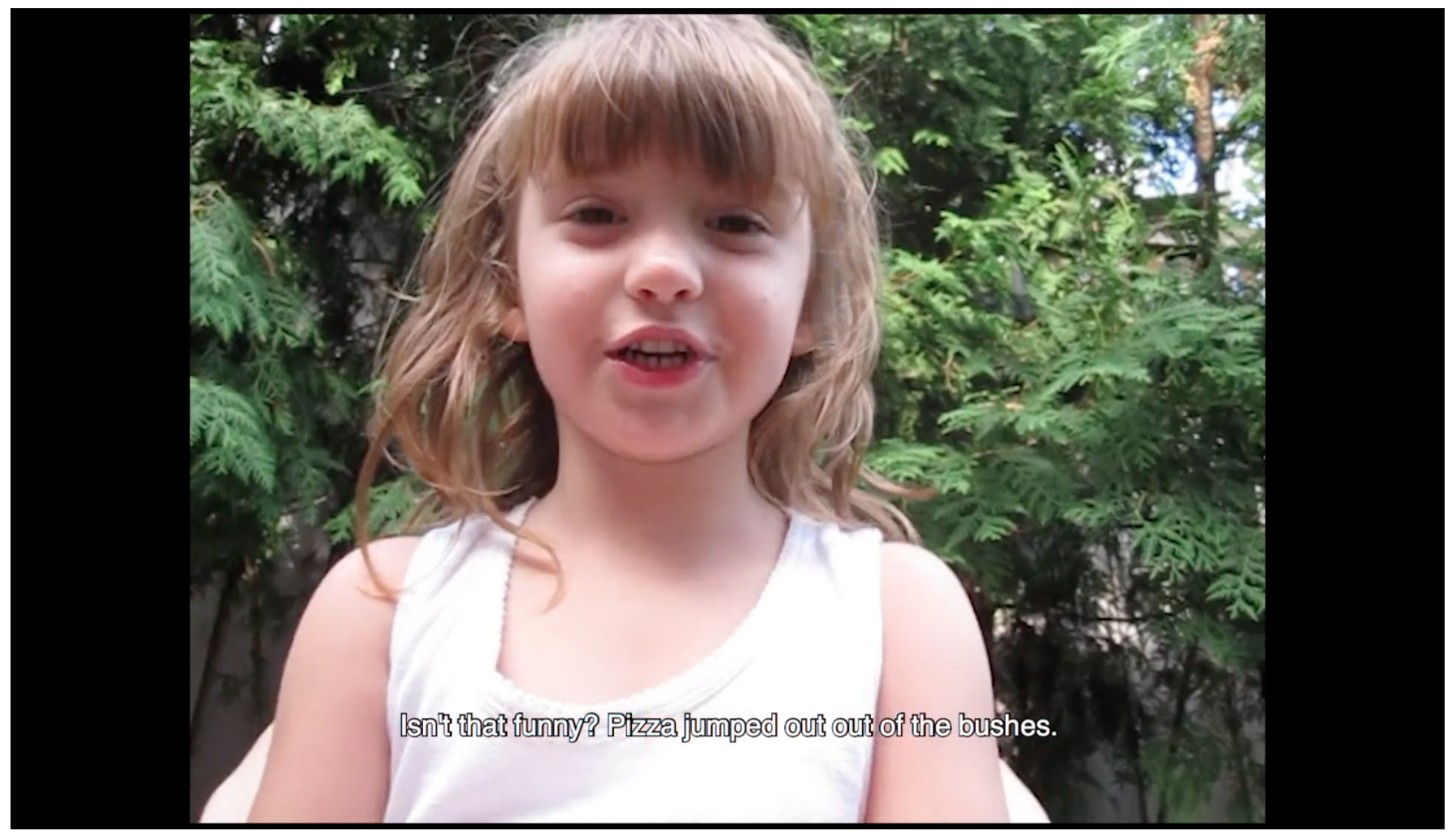




\section{[iPhone footage]}

The first day I cried was the day I brought home the puppy. He told me to take it back.

[Lisa: go get him!]

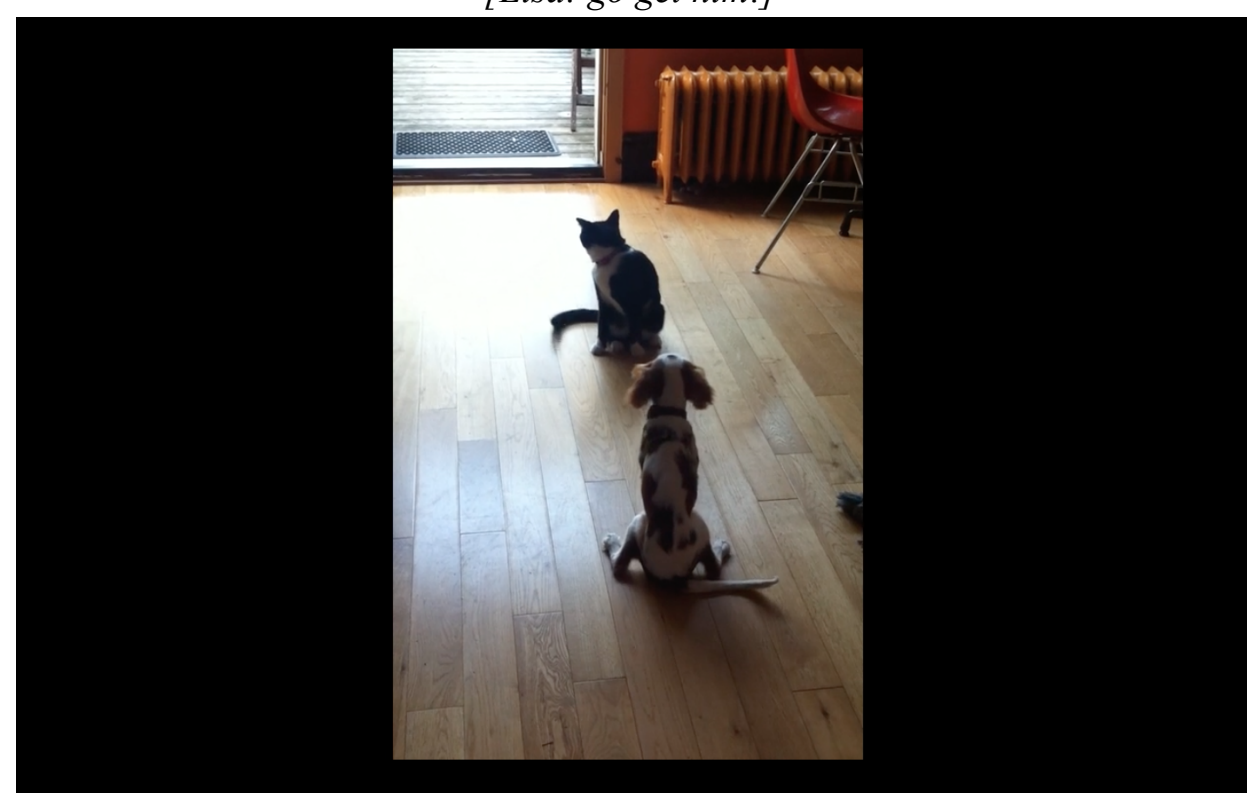

He started to hate everything. Nothing I did was ever good enough for him. He was mad that I wasn't coming home every night to cook dinner, said that I was doing too much, going too fast. He wanted me to ask permission for everything I did.

Later I found out that he had signed onto my Facebook and was monitoring all of my conversations with friends for months and months. He wanted control. We were entering spousal abuse territory, but I didn't want to believe it.

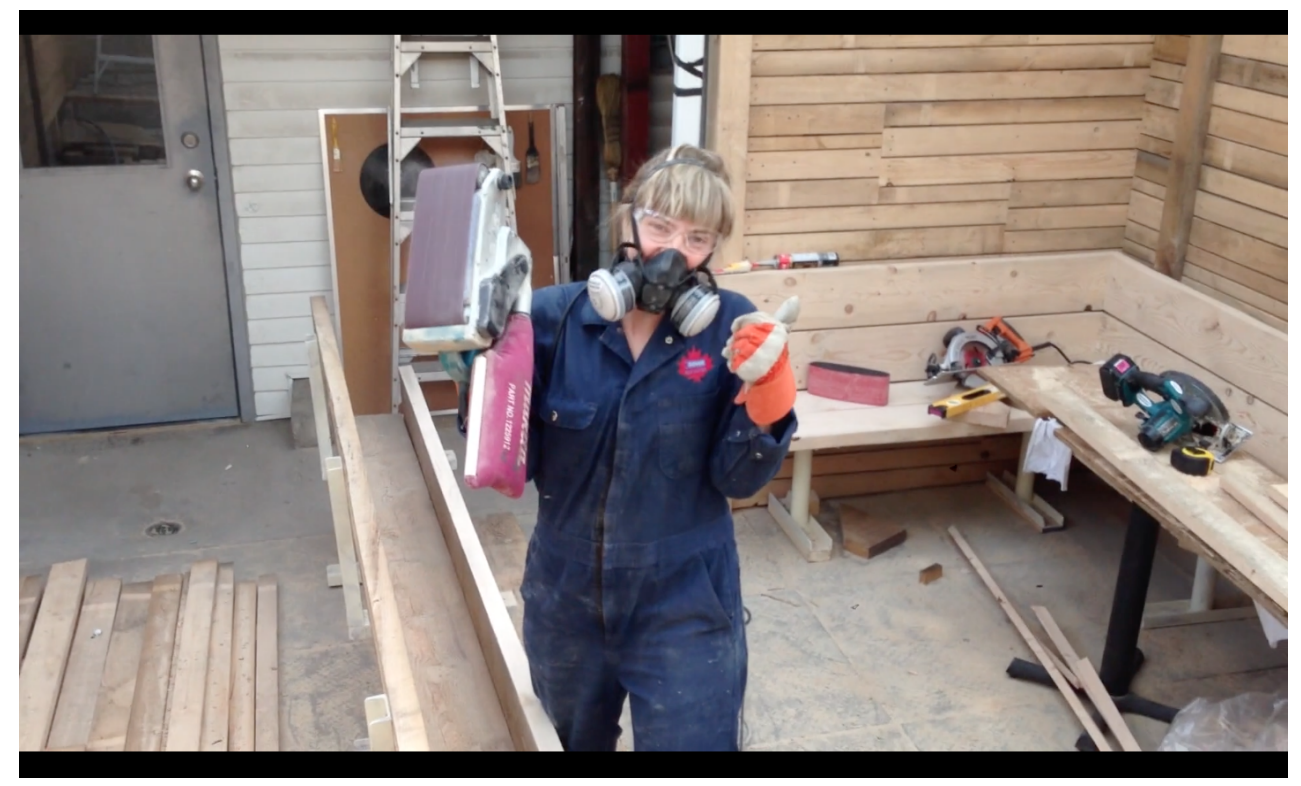


He started to become an abusive at the café. He was telling customers off, unplugging their laptops, turning off $W i-F i$, but by then it was too late.

I had to make it work because all of my life savings were gone into the business. The more that I did to keep our family together and the business running, the worse things became between us. He began to resent me.

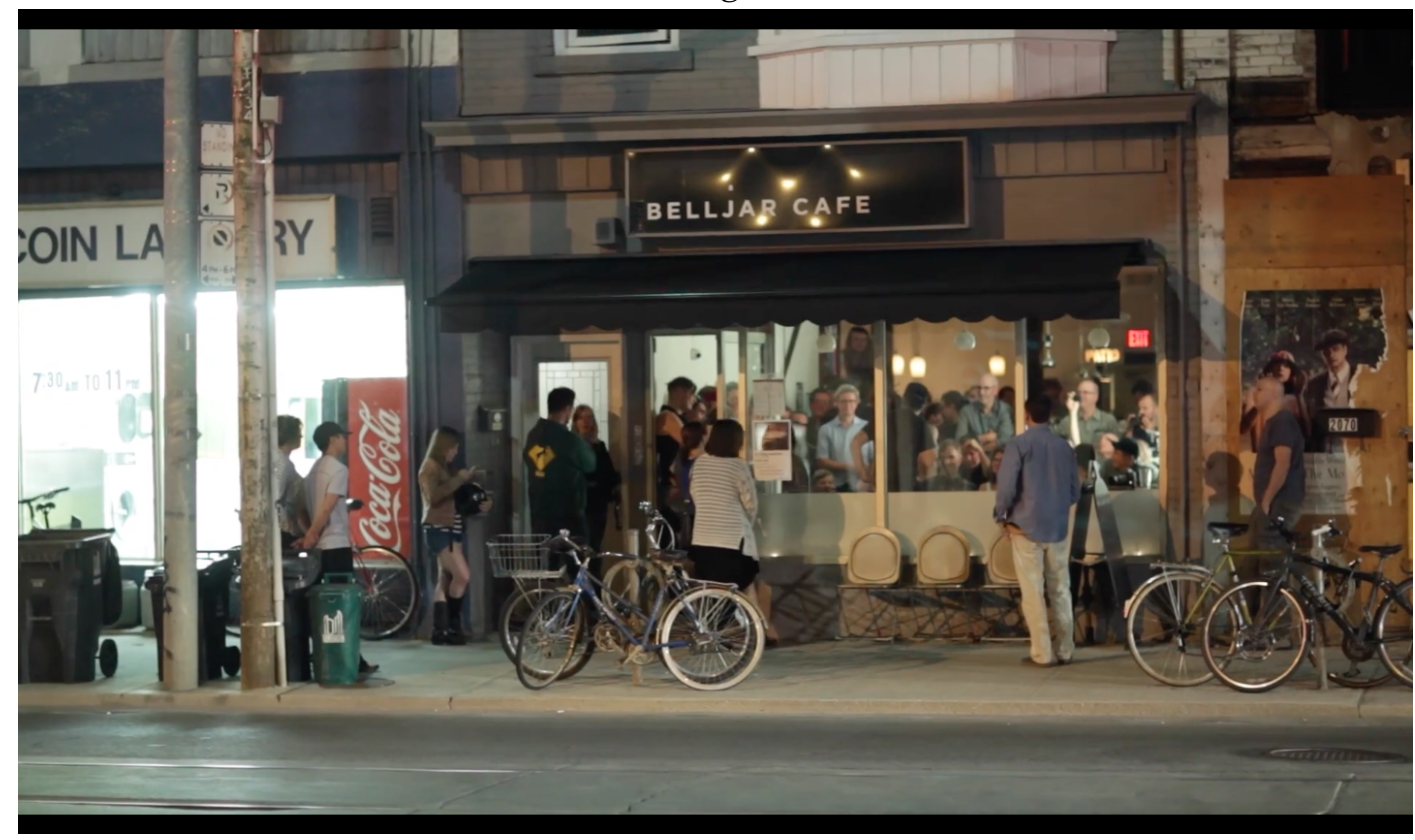

[Time-lapse footage]

I needed to escape the city; I couldn't breathe. My only refuge was time at a friend's cottage

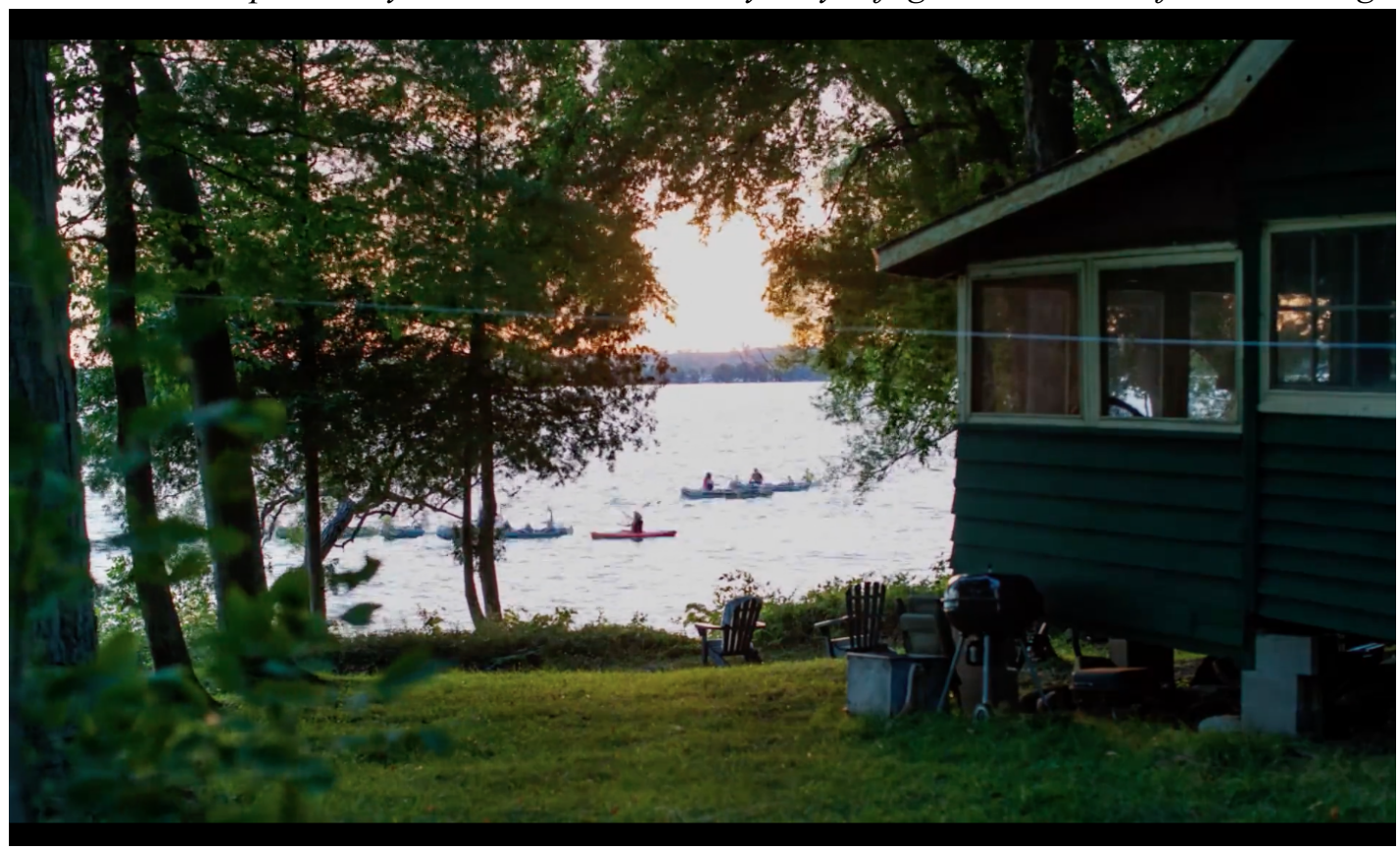


I realized that something I needed to change. I asked him to come for therapy, he refused. There's nothing wrong with me he said. There is something wrong with you Lisa.

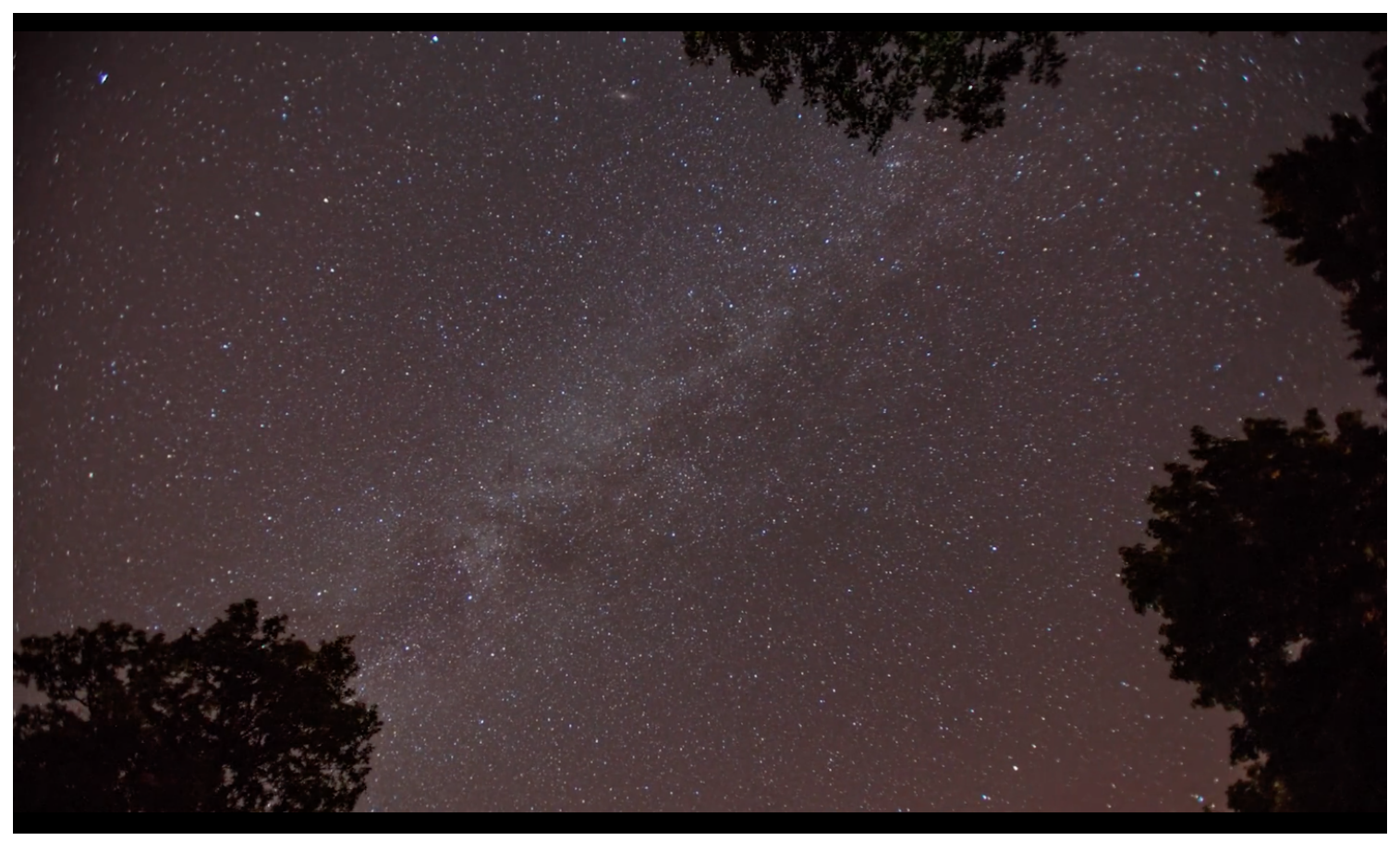

He punched walls in our house.

That summer I called the police on him five times, but they refused to intervene unless there was physical abuse.

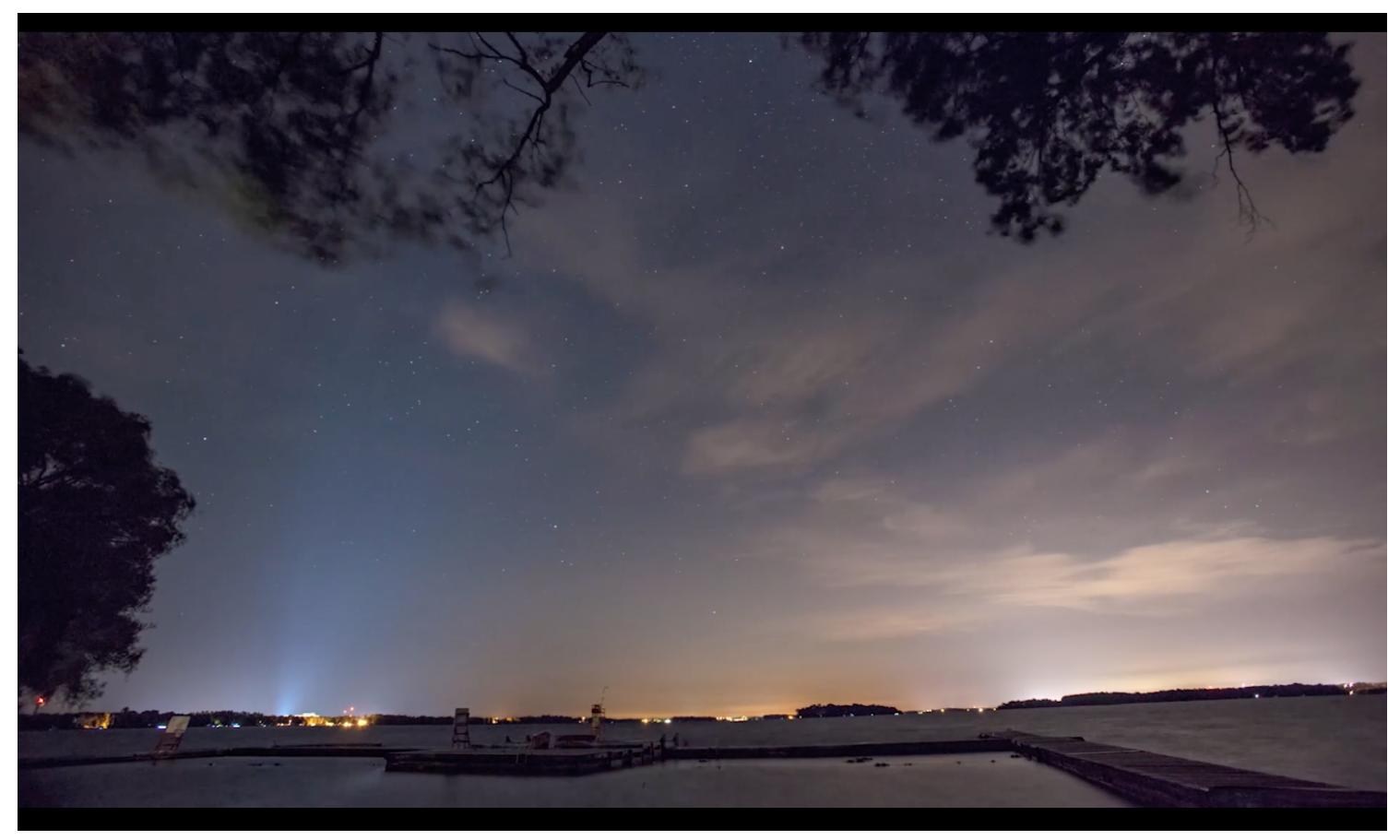




\section{[ Phone call with vet's office]}

Receptionist: Hello, how can I help you?

Lisa: $\quad$ I am wondering if it's possible to get a copy of a record for my cat pizza? A little while back he got kicked.

Receptionist: $\quad$ And your first name?

Lisa: $\quad$ Lisa. And it's for pizza. Pizza cat. I brought him in, he was quite sick. He hadn't eaten, he was peeing blood and vomiting.

I found him like that five days after it happened.

Receptionist: $\quad$...hasn't been eating or drinking... vomiting yellow.

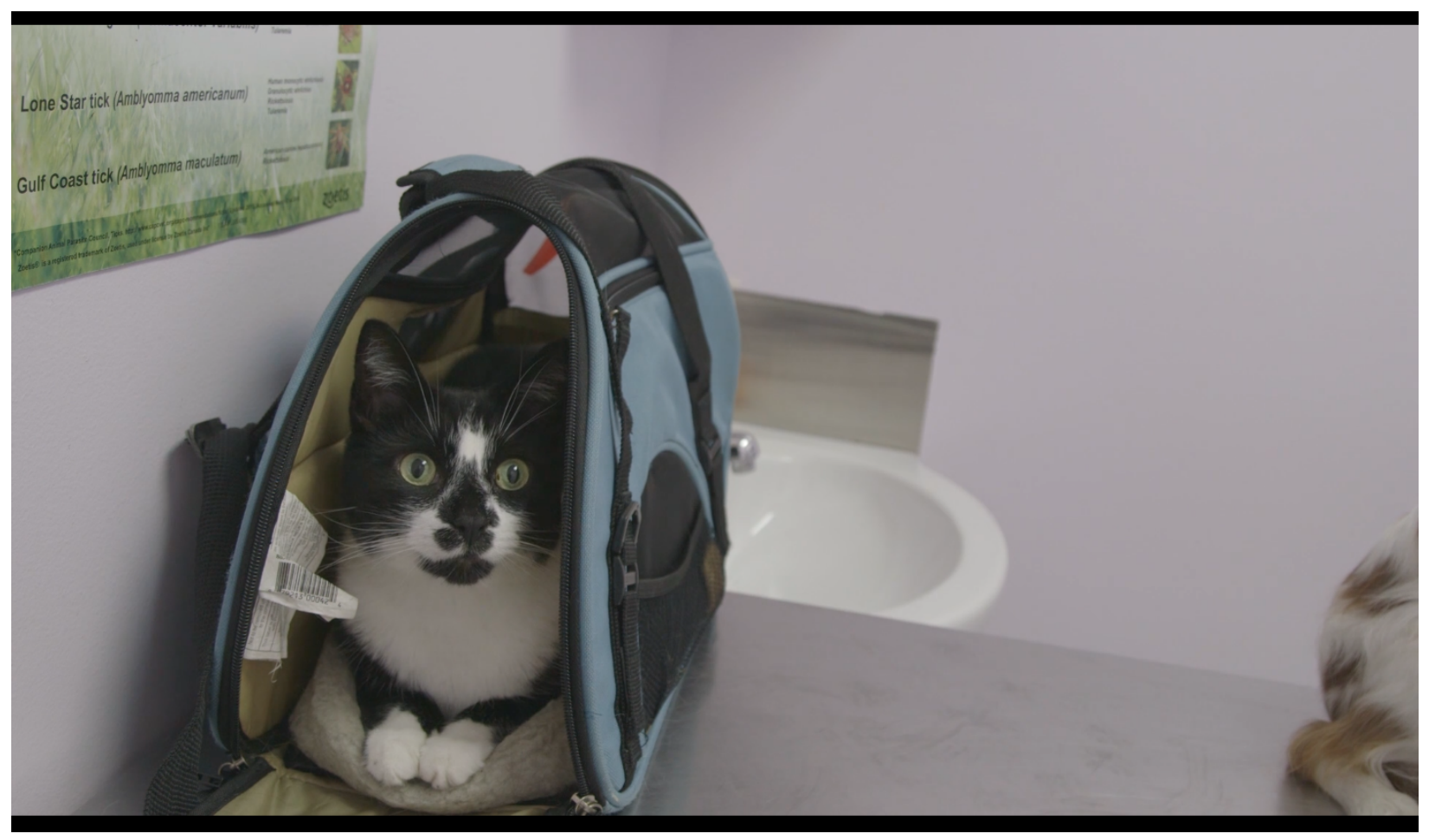

Rage makes him blind. 
I decided to sell my house as a way to get away from his rage.

But that didn't stop him from verbally attacking me on the street, in the cafe, or in front of our daughter. Teaching her that this is how we talk to mommy now.

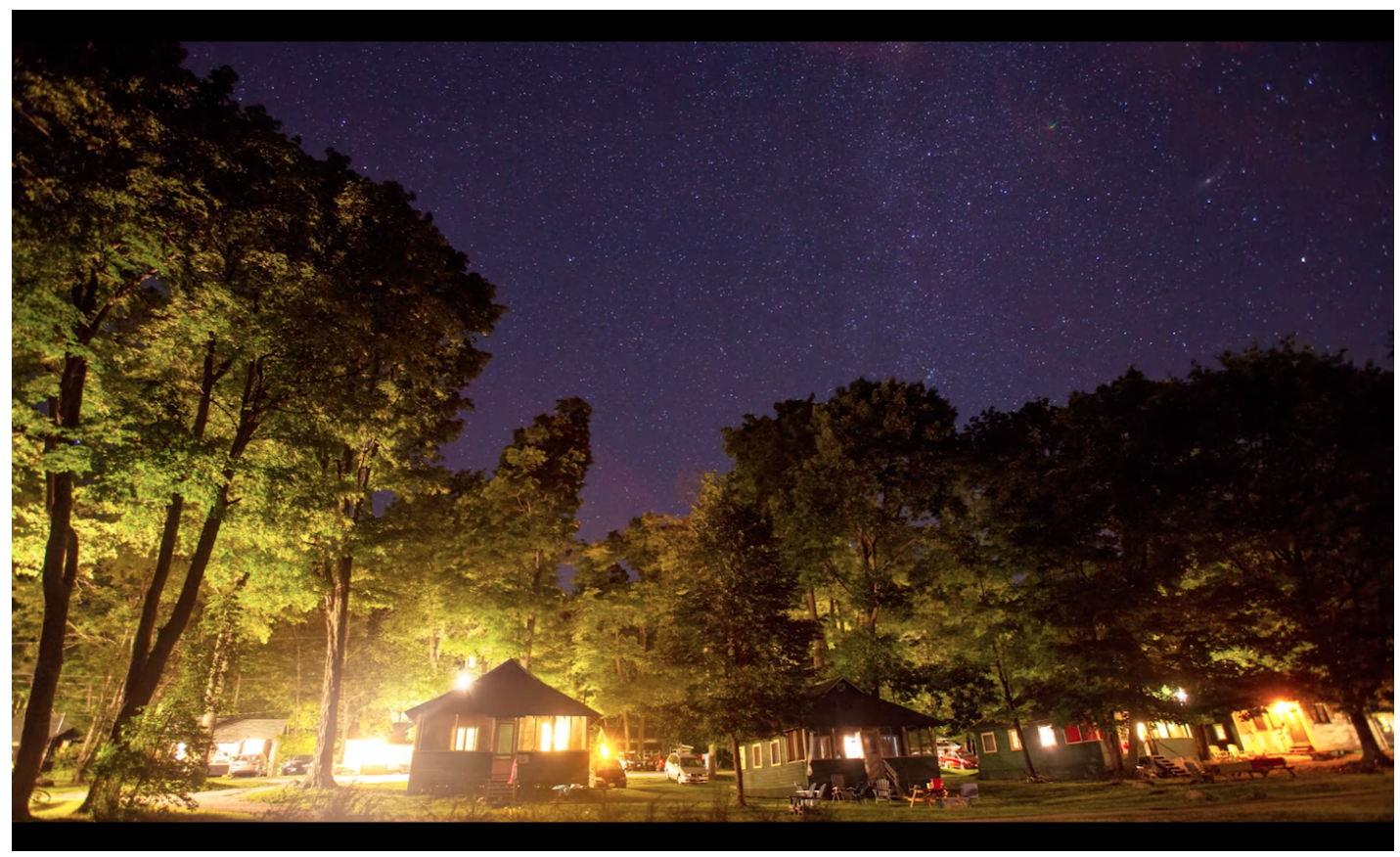

I was just so isolated in my marriage and my life at the time and I didn't feel I could reach out for help. I stayed and try to work out our problems because I felt like we could work things out.

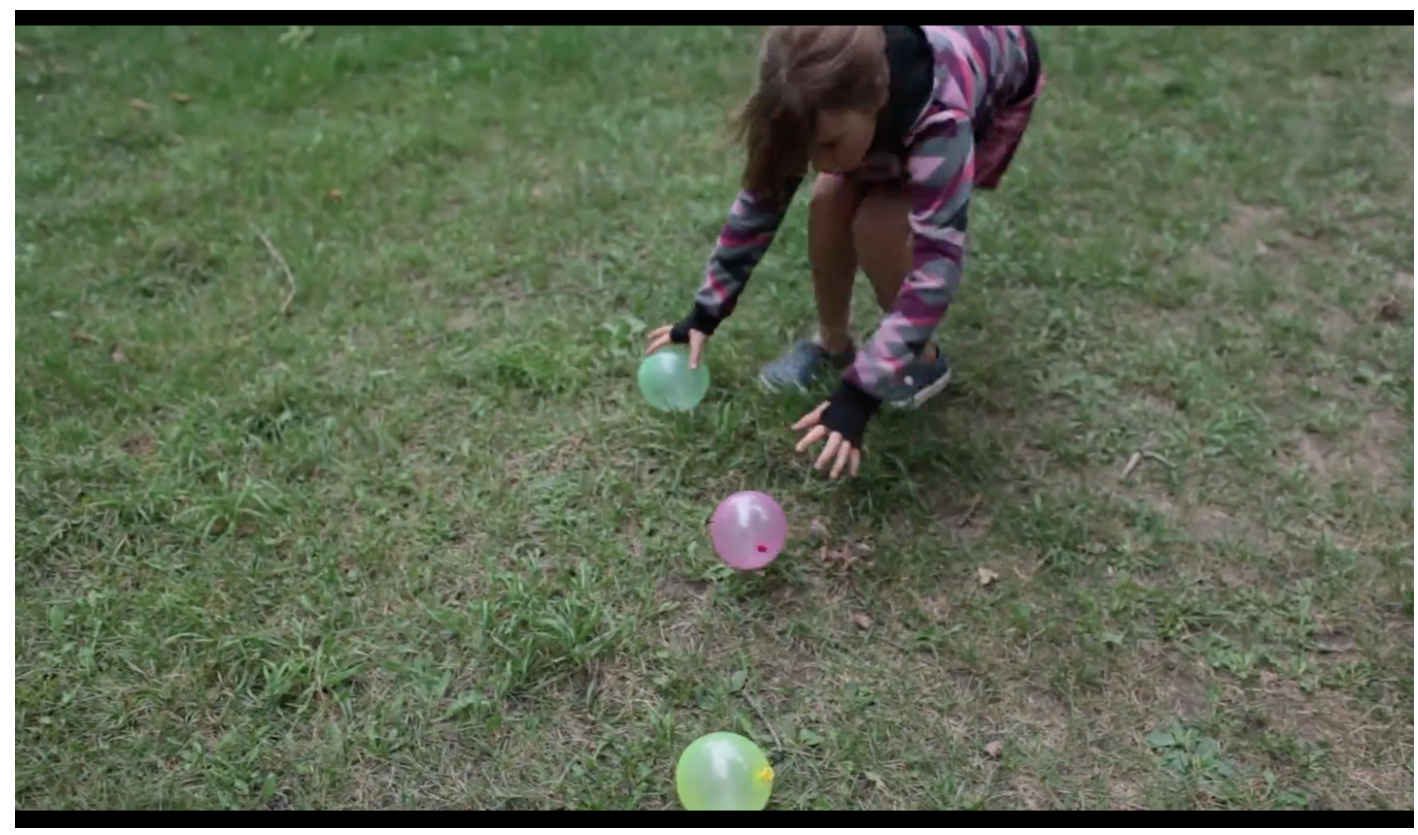


The stuff the lawyers were saying made no sense to me, we had ended, shit hit the fan, and we were talking divorce. We met in separate rooms; we fight over who owned the cafe. I had given him control of my money and shared everything with him, and now it was all gone. I believed that we had a future, but I couldn't live with abuse.

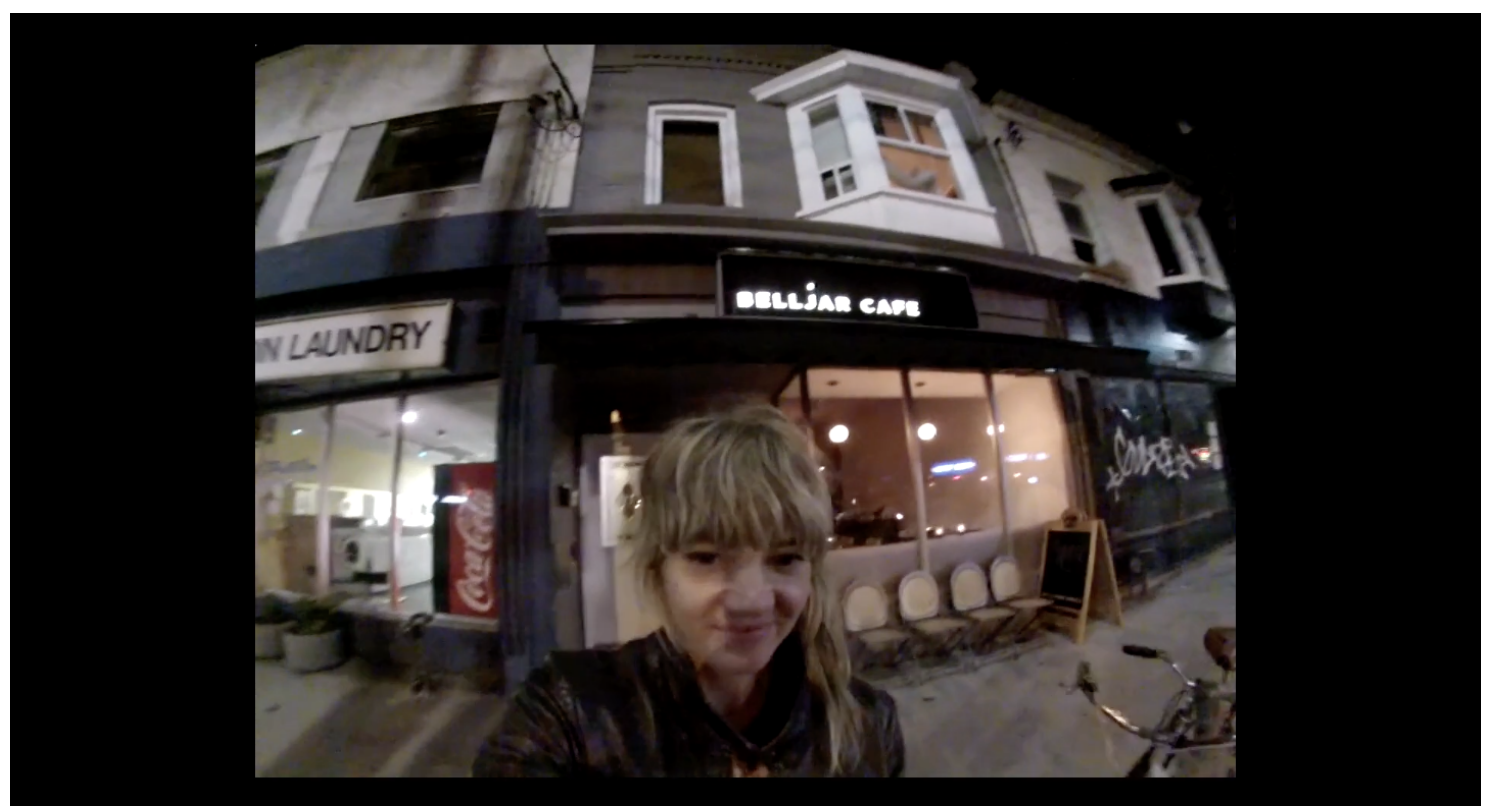

He took everything, but I gained my freedom. My place in the world has changed. I worry that I'll never fall in love with someone that I can trust, but that's the price of freedom.

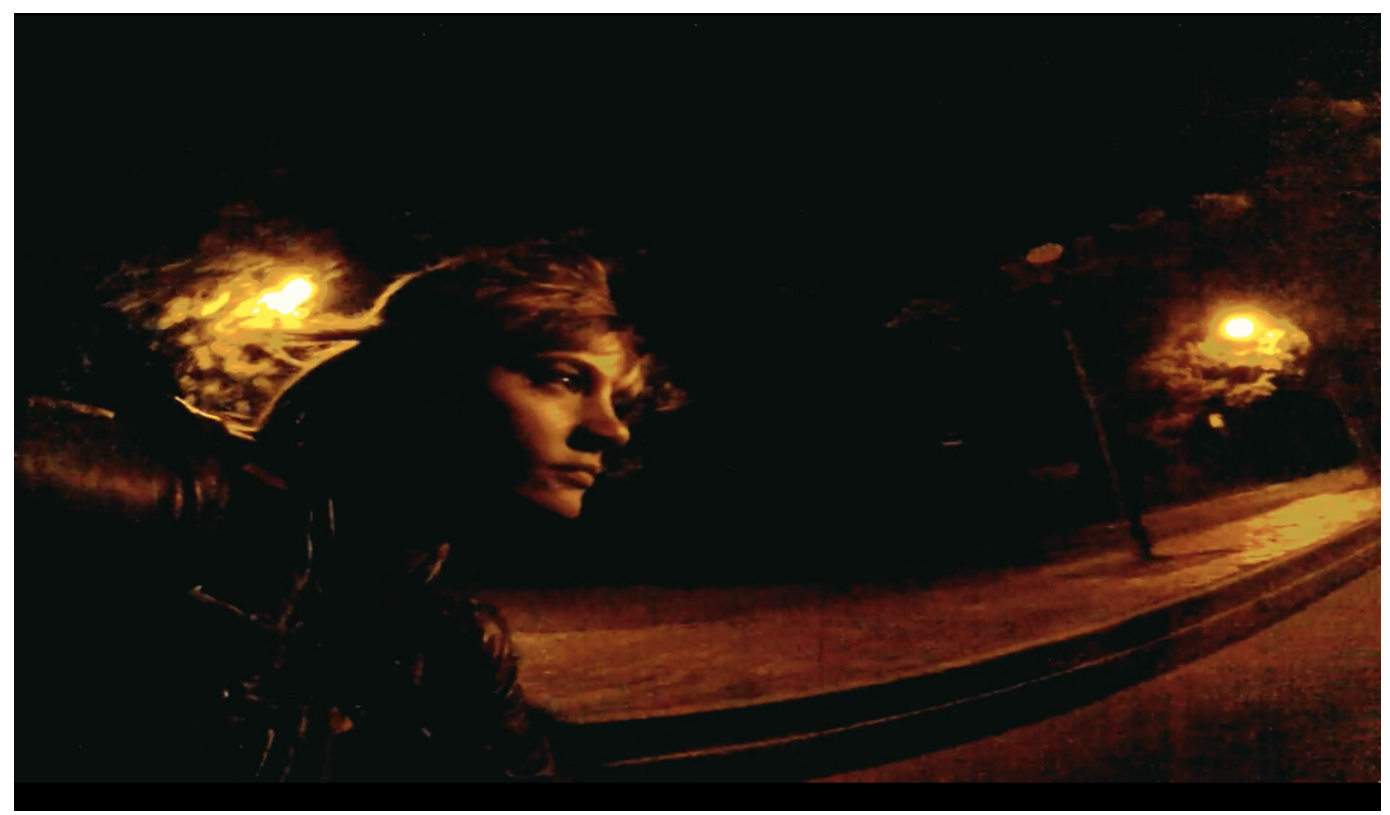

I owe my daughter a better life. I am a living example to her now and I won't be told that I can 't. I know I can.

I will. 


\section{CONCLUSION}

My film came about due to a subconscious need to tell my story. I had lived through a trauma that was too big for me to recognize. I hadn't dealt well with the reality when it happened, and I had put off facing it when it ended. Plus, it didn't seem to actually end; removing myself from the situation meant my assailant had no reason for restraint because I was no longer his wife. He began a campaign of revenge.

So, while I was adjusting to my break-up and living as a single parent with all that comes with it financial strain, solo parenting, heartbreak and loneliness--I was also experiencing parental alienation as my child attacked me physically each time, after coming back from her father's house.

My daughter was a witness to the ongoing abuse, both during and after the marriage. Her father verbally attacked me in public, and badmouthed me in private, so that I appeared to be the root of the problem, the cause of the destruction of our family and reason she had lost everything in her world.

I sold my house because my husband kept punching the walls and I could not stay there. I was financially reliant on him; I needed the money to start over. I did not realize my husband would use lawyers against me to extend his abuse through legal means, causing me to end up being so financially desperate that I would go to the food bank three years after leaving him, so that I could feed my daughter.

Rather than allow this situation to beat me down, and ruin the rest of my life, I decided to go back to school at Ryerson. I wanted to take control, have a positive future for my daughter and myself.

The situation in which I live, having a co-parent who clearly has mental illness and refuses to acknowledge or seek treatment for it, is a situation I will have to deal with for the rest of my life. My daughter will always have her father. It is not my place to tell her that he is a bad man, because every child has two parents and needs them both. It is only my place to give my daughter positive male rolemodels, a happy home and safe place to live. I continue to give support for her mental health needs with a talk therapist. I cannot change or affect the other parent, as every attempt to do so leads to a war. I will not interact with her father in any way as the abuse is still ongoing, but I will be fully myself and not allow him control in my life or to silence my voice, as that would be a continuation of what came before.

Making this film has allowed me to create a new narrative to my story, to find my voice and use it for positive change. 
I set into history my perspective, as it is the only story, I have a right to tell. My husband demanded silence throughout our marriage. What happened behind closed doors, happened because I was isolated and alone. It is a tactic used by perpetrators of violence, to control their victims.

I am no longer separated from society, and I hope that by speaking out, I may give support and guidance to others who are experiencing similar situations. There is no reason for any woman, or any person from any walk of life, to be silent about the atrocities that have happened to them. By speaking out, we create a space for change. 


\section{BIBLIOGRAPHY}

Caruth, Cathy. Trauma: Explorations in Memory. The John Hopkins University Press, Baltimore and London.1995.

Romito, Patrizia. "Tactics for hiding male violence.” A deafening silence: Hidden violence against women and children. University Press Scholarship Online. Print publication date: 2008 Print ISBN-13: 9781861349613 Published to Policy Press Scholarship Online: March 2012 DOI: 10.1332/policy press/9781861349613.001.0001

Hlavka, Kruttschnitt, and Carbone-López. Re Victimizing the Victims? Interviewing Women About Interpersonal Violence. University of Minnesota. Journal of Interpersonal Violence. Volume 22 Number 7. July 2007 894-920 (C) 2007 Sage Publications. 10.1177/0886260507301332

http://jiv.sagepub.com hosted at http://online.sagepub.com

Czerny, Astra B. Lassiter, Pamela S. Hoon Lim, Jae. Post-Abuse Boundary Renegotiation: Healing and Reclaiming Self After Intimate Partner Violence. Journal of Mental Health Counseling. Volume 40, No 3. July 2018. Pages 211-225. Doi: 10.17744/mehc.40.3.03

Ouellet-Morin, Fisher, York-Smith, Fincham-Campbell, Moffitt, and Arseneault. INTIMATE PARTNER VIOLENCE AND NEW-ONSET DEPRESSION: A LONGITUDINAL STUDY OF WOMEN'S CHILDHOOD AND ADULT HISTORIES OF ABUSE. DEPRESSION AND ANXIETY, Vol. 32. (2015) Wiley Periodicals. 2015. Pages 316-324

Thoresen, Siri and Øverlien, Carolina. Trauma Victim: Yes or No? Why It May Be Difficult to Answer Questions Regarding Violence, Sexual Abuse, and Other Traumatic Events. Norwegian Centre for Violence and Traumatic Stress Studies. Violence Against Women

Volume 15 Number 6. June 2009 699-719. Sage Publications. 10.1177/1077801209332182

Coulter, Stephen and Mooney, Suzanne. Much More Than PTSD: Mothers' Narratives of the Impact of Trauma on Child Survivors and Their Families. Contemp Fam Ther (2018) 40:226-236

DOI 10.1007/s10591-017-9408-z

Hass-Cohen, Noah. Partnering of Art Therapy and Clinical Neuroscience. Art Therapy and Clinical Neuroscience. Jessica Kingsley Publishers, 2008. ProQuest Ebook Central, http://ebookcentral.proquest.com/lib/ryerson/detail.action?docID=366687.

Anonymous . Silence speaks volumes in marriage. Chicago Tribune ; Chicago, Ill. [Chicago, Ill]28 Sep 2011: 7.

Hayes, Brittany E. Abusive Men's Indirect Control of Their Partner During the Process of Separation. J Fam Viol (2012) 27:333-344. DOI 10.1007/s10896-012-9428-2 
Murraya, Spencera, Stickla, Croweb. See the Triumph Healing Arts Workshops for Survivors of Intimate Partner Violence and Sexual Assault, JOURNAL OF CREATIVITY IN MENTAL HEALTH 2017, VOL. 12, NO. 2, 192-202. https://doi.org/10.1080/15401383.2016.1238791

Schouten, de Niet, Knipscheer, Kleber, Hutschemaekers. The Effectiveness of Art Therapy in the Treatment of Traumatized Adults: A Systematic Review on Art Therapy and Trauma. TRAUMA, VIOLENCE \& ABUSE 2015. Vol. 16(2) 220-228. @The Author(s) 2014. Reprints and permission: doi:10.1177/1524838014555032 tva.sagepub.com

Williams, Tuffin and Niland. "It's like he just goes off, BOOM!": mothers and grandmothers make sense of child-to-parent violence. School of Psychology, Massey University, Wellington, New Zealand. Doi.10.1111/cfs.12273

Mills \& Kellington. Using group art therapy to address the shame and silencing surrounding children's experiences of witnessing domestic violence. International Journal of Art Therapy, March 2012. 17(1). Pages 3-12.

Rakovec-Felser, Zlatka. Domestic violence and abuse in intimate relationship from public health perspective. Department for Health Psychology Faculty of Medicine, University of Maribor, Slovenia.

Renov, Micheal. The subject of documentary. Minneapolis: University of Minnesota Press, 2004.

Citron, Michelle. Narrate the unspeakable: how we talk when words fail. Film Archive archives. Valencia Issue 57/58. (Oct 2007-Feb 2008): 260-289, 307.

Lynch, David 'Catching the Big Fish: Meditation Consciousness and Creativity'; Acclaimed Director Discusses Transcendental Meditation. Tarcher, 2006.

Sullivan, Graeme. Research Acts in Art Practice. Studies in Art Education, Vol. 48, No. 1, Arts-Based Research in Art Education.2006. pp. 19-35 Published by: National Art Education Association http://www.jstor.org/stable/25475803

Cooper, Sarah. Selfless Cinema? "Chris Marker: Love Death and Documentary” Ethics and French documentary. Oxford: Legenda, 2006.

Harper, Douglas. Talking about Pictures: A Case for photo elicitation. Visual Studies, Vol. 17, No. 1. 2002.

Russell, Catherine. Autoethnography: Journeys of the Self. Experimental Ethnography, Duke University Press. 1999.

Understanding the Impact of Trauma. Trauma-Informed Care in Behavioral Health Services. Treatment Improvement Protocol (TIP) Series, No. 57. Center for Substance Abuse Treatment (US). Rockville (MD): Substance Abuse and Mental Health Services Administration (US); 2014. 
Long Term Effects of Domestic violence

https://www.acesdv.org/domestic-violence-graphics/impact-on-survivors/

Common mental effects of domestic violence

http://www.joyfulheartfoundation.org/learn/domestic-violence/effects-domestic-violence\#footnote-3

Bunston, Franich-Ray, Tatlow. A Diagnosis of Denial: How Mental Health Classification Systems Have Struggled to Recognise Family Violence as a Serious Risk Factor in the Development of Mental Health Issues for Infants, Children, Adolescents and Adults. Brain Sciences. 2017, 7(10), 133;

https://doi.org/10.3390/brainsci7100133

Financial Abuse: Women's experiences of Domestic Violence and Abuse

http://www.healthtalk.org/peoples-experiences/domestic-violence-abuse/womens-experiences-domesticviolence-and-abuse/coercive-controlling-behaviour

Schroeder, Michael. Is Your Chronic Procrastination Actually a Matter of Mental Health? US News. https:/health.usnews.com/wellness/mind/articles/2017-08-03/is-your-chronic-procrastination-actually-amatter-of-mental-health

Intersection of Animal Abuse and Interpersonal Abuse. https://www.youtube.com/watch?v=e3xB9QXJ_0

Feder, Wilson and Austin. Court-Mandated Interventions for Individuals Convicted of Domestic Violence. https://www.campbellcollaboration.org/media/k2/attachments/1043_R.pdf

Pets In The Crossfire Of Family Violence.

http://www.mnvideovault.org/mvvPlayer/customPlaylist2.php?id=16963\&select_index=0\&popup=yes $\# 0$

Trapnell, Paul D.,Campbell, Jennifer D. Private self-consciousness and the five-factor model of personality: Distinguishing rumination from reflection. Journal of Personality and Social Psychology, Vol 76(2), Feb 1999, 284-304

Kennedy Dugan, Meg \& Hock, Roger R. It's My Life Now: Starting Over After an Abusive Relationship or Domestic Violence (2nd Edition)

http://www.impactpublications.com/itsmylifenowstartingoverafteranabusiverelationshipordomesticviolen ce.aspx

James D. Kirylo (Ed.), A Critical Pedagogy of Resistance: 34 Pedagogues We Need to Know, 17-20. (C) 2013 Sense Publishers. All rights reserved. https://ink-springercom.ezproxy.lib.ryerson.ca/book/10.1007\%2F978-94-6209-374-4

Artist Video: My Private Life II. Author: Jill Daniels. Format: 16:9 split-screen video. Duration: 25' 24". Published: February 2017. http://screenworks.org.uk/archive/volume-7/my-private-life-ii 
Katz \& Katz, "Ethics and the Perception of Ethics in Autobiographical Film," in Image Ethics: The Moral Rights of Subjects in Photographs, Film, and Television, ed. Gross et al. (Cary, NC, USA: Oxford University Press, 1991), 127-128.

Artist Video: DP/30: Heart of a Dog, Laurie Anderson.

https://www.youtube.com/watch?v=zggApN8cOG0

Frederick Wiseman: The Filmmaker Who Shows Us Ourselves

https://www.nytimes.com/2017/04/06/movies/frederick-wiseman-documentaries.html

Beyond alphabets: An interview with Stephan A. Tyler. POMO Magazine, 2(1):11-30, 1996. Interviewed by Scott A. Lukas, November 30, 1995.

https://www.academia.edu/273931/Beyond_Alphabets_An_Interview_with_Stephen_A._Tyler

Laura Rascaroli (2009) The Personal Camera: Subjective Cinema and the Essay Film.

https://www.euppublishing.com/doi/abs/10.3366/film.2010.0058

Park-Fuller, inda M. Performing Absence: The Staged Personal, Narrative as Testimony. Text and Performance Quarterly. Vol. 20, No. 1, January 2000, pp. 20-42

Nichols, Bill. Documentary Reenactment and the Fantasmatic Subject. Critical Inquiry. Vol. 35, No. 1 (Autumn 2008), pp. 72-89. Published by: The University of Chicago Press DOI: 10.1086/595629 https://www.jstor.org/stable/10.1086/595629

Jacobs, Sean.'Enjoy Poverty': Interview with Renzo Martens.

https://africasacountry.com/2010/07/poverty-for-sale/

Renov, Michael. Family Secrets: Alan Berliner's "Nobody's Business" and the (American) Jewish Autobiographical Film. Framework: The Journal of Cinema and Media. Vol. 49, No. 1 (SPRING 2008), pp. 55-65. Published by: Drake Stutesman; Wayne State University Press

https://www.jstor.org/stable/41552511

Freeman, John. Trying Not to Lie...and Failing: Autoethnography, Memory, Malleability. Falmouth University. The Qualitative Report Volume 20 | Number 6 How To Article 15. 2015.

https://core.ac.uk/download/pdf/51087668.pdf

Vance Kepley and Rebecca Swender. "Claiming the Found: Archive Footage and Documentary Practice." The Velvet Light Trap 64 (2009): 3-10. https://muse.jhu.edu/ (accessed August 20, 2019).

Ruby, Jay. The Image Mirrored: Reflexivity and the Documentary Film. Journal of the University Film Association. Vol. 29, No. 4, THE DOCUMENTARY IMPULSE: CURRENT ISSUES (Fall 1977), pp. 31.1Published by: University of Illinois Press on behalf of the University Film \& Video Association https://www.jstor.org/stable/20687384 
Williams, Linda \& Ruby Rich, B. (1981). The Right of ReVision: Michelle Citron's "Daughter Rite". Film Quarterly, Vol. 35, No. 1 (Autumn, 1981), pp. 17-22 Published by: University of California Press Stable URL: https://www.jstor.org/stable/1212076

Rakovec-Felser, Zlatka. "Domestic Violence and Abuse in Intimate Relationship from Public Health Perspective.” Health psychology research vol. 2,3 1821. 22 Oct. 2014, doi:10.4081/hpr.2014.1821

Navarro, Vinicius. "Nonfictional Performance from Portrait Films to the Internet." Cinema Journal 51, no. 3 (2012): 136-41. http://www.jstor.org/stable/23253897.

Linda M. Park-Fuller (2000) Performing absence: The staged personal narrative as testimony, Text and Performance Quarterly, 20:1, 20-42, DOI: 10.1080/10462930009366281

Cuevas, Efren. (2013). Home movies as personal archives in autobiographical documentaries. Studies in Documentary Film. 17. 17-29. 10.1386/sdf.7.1.17_1.

Hopkins, R. Episodic Memory as Representing the Past to Oneself. 201.4 5: 313.

https://doi.org/10.1007/s13164-014-0184-5 